\title{
A stable explant culture of HER2/neu invasive carcinoma supported by alpha-Smooth Muscle Actin expressing stromal cells to evaluate therapeutic agents Marie P Piechocki
}

Address: Department of Breast Cancer Immunotherapy, Wayne State University and Karmanos Cancer Center, Detroit, MI, USA Email: Marie P Piechocki - piechock@karmanos.org

Published: 24 April 2008

BMC Cancer 2008, 8:119 doi:10.1186/147|-2407-8-119
Received: 24 October 2007

Accepted: 24 April 2008

This article is available from: http://www.biomedcentral.com/I47/-2407/8/II9

(c) 2008 Piechocki; licensee BioMed Central Ltd.

This is an Open Access article distributed under the terms of the Creative Commons Attribution License (http://creativecommons.org/licenses/by/2.0), which permits unrestricted use, distribution, and reproduction in any medium, provided the original work is properly cited.

\begin{abstract}
Background: To gain a better understanding of the effects of therapeutic agents on the tumor microenvironment in invasive cancers, we developed a co-culture model from an invasive lobular carcinoma. Tumor cells expressing HER2/neu organize in nests surrounded by alpha-Smooth Muscle Actin ( $\alpha-S M A)$ expressing tumor stroma to resemble the morphology of an invading tumor. This co-culture, Mammary Adenocarcinoma Model (MAM-I) maintains a I:I ratio of HER2/neu positive tumor cells to $\alpha$-SMA-reactive stromal cells and renews this configuration for over 20 passages in vitro.
\end{abstract}

Methods: We characterized the cellular elements of the MAM-I model by microarray analysis, and immunocytochemistry. We developed flow cytometric assays to evaluate the relative responses of the tumor and stroma to the tyrosine kinase inhibitor, Iressa.

Results: The MAM-I gene expression profile contains clusters that represent the ErbB-2 breast cancer signature and stroma-specific clusters associated with invasive breast cancers. The stability of this model and the ability to antigenically label the tumor and stromal fractions allowed us to determine the specificity of Iressa, a receptor tyrosine kinase inhibitor, for targeting the tumor cell population. Treatment resulted in a selective dose-dependent reduction in phospho-pMEKI/2 and PP44/42MAPK in tumor cells. Within $24 \mathrm{~h}$ the tumor cell fraction was reduced I.9-fold while the stromal cell fraction increased $>3$-fold, consistent with specific reductions in phospho-pp44/42 MAPK, MEKI/2 and PCNA in tumor cells and reciprocal increases in the stromal cells. Erosion of the tumor cell nests and augmented growth of the stromal cells resembled a fibrotic response.

Conclusion: This model demonstrates the specificity of Iressa for HER2/neu expressing tumor cells versus the tumor associated myofibroblasts and is appropriate for delineating effects of therapy on signal transduction in the breast tumor microenvironment and improving strategies that can dually or differentially target the tumor and stromal elements in the microenvironment.

\section{Background}

The development of targeted therapies for the specific inactivation of receptor tyrosine kinase oncogenes involved in tumor initiation and progression has lead to the ability to target signal transduction as a modality for cancer treatment and prevention [1,2]. ZD1839 (gefitinib, Iressa $\left.{ }^{\circledast}\right)$, an orally active, selective EGFR-Tyrosine Kinase Inhibitor (TKI) that blocks signal transduction pathways 
implicated in proliferation and survival of cancer cells and other host-dependent processes that promote cancer growth $[3,4]$. To date, we have already demonstrated the efficacy of Iressa against mammary and salivary gland tumor cell lines derived from transgenic mice that overexpress the activated rat HER2/neu [5,6]. These studies focused mainly on the direct effects of Iressa on tumor cells. More recently, we have determined that Iressa can also prevent the outgrowth and progression of mammary and salivary gland cancers from early hyperplasias [7]. During these studies, we observed significant changes in the microenvironment as a result of treatment. It has been widely recognized that the tumor microenvironment plays a major role in dictating tumor behavior and progression as well as response to therapy. To better define, characterize and understand the effects of Iressa on the tumor and its microenvironment we developed a stable model of HER2/neu positive mammary tumor cells in coculture with alpha-Smooth Muscle Actin ( $\alpha$-SMA)-positive stromal cells that recapitulate the microenvironment of an invasive carcinoma.

Several organotypic breast cancer models and co-cultures have been described. These include admixtures of tumor cells and fibroblasts or stromal cells [8-10], mammary tumor cells grown as spheroids [11] or 3-dimensional scaffolds [12], organ cultures [13] and orientated lumen forming acinar cultures $[14,15]$. These can be laborious to maintain and difficult to analyze without specialized reagents and equipment. We have developed a self-renewing model that circumvents some of these technical barriers and has proven to be stable, reliable and user friendly. We have identified several advantages to the Mammary Adenocarcinoma Model (MAM-1) for screening preventive and therapeutic agents, emphasizing the need to evaluate therapies in the context of homotypic microenvironment.

MAM-1 is immortal and faithfully recapitulates the morphology of invasive carcinomas that arise in BALB-NeuT transgenic mice, a model for HER2/neu driven lobular carcinoma [16]. MAM-1 grows rapidly in vitro and in vivo and maintains a 1:1 tumor-to-stroma ratio with routine passaging. This ratio can be manipulated with differential trypsinizations. This configuration is stable for over 20 passages. In MAM-1 there is no need for separate cultures, special media or culture conditions. MAM-1 can be used to test any agent or type of therapy, especially HER 2 and stroma targeted therapies including biological and immunotherapies. Using MAM-1 treatment effects can be followed by out growth assays in vitro and in vivo (residual tumorigenic potential) in $\mathrm{BALB} / \mathrm{c}$ mice. A key advantage to MAM-1 is the ability to simultaneously evaluate tumor cells and stromal cells using convenient markers (i.e., $\alpha$ SMA, HER2) that are stable and suitable for flow cytometry (FACs) and immunofluorescent imaging. Further- more, cells can be fractioned, based on these stable markers, to generate lysates for IP, Western blot, and multiplex bead arrays or generate RNA and DNA for microarray and methylation analyses. Finally, MAM-1 is suitable for use in assays that evaluate invasive and angiogenic potential of cells.

In this paper we describe the development of the MAM-1 co-culture model and methods for manipulating and analyzing it to evaluate mechanism(s) of the receptor tyrosine kinase inhibitor, Iressa. We further resolve a dynamic reciprocity between tumor and stromal cell populations during growth and treatment.

\section{Methods \\ BALB-NeuT Transgenic animals}

Two stock BALB-NeuT transgenic males were obtained through collaboration with Dr. Guido Forni. The BALBNeuT strain originated from a transgenic CD1 randombred breeder male mouse (no. 1330) carrying the mutated rat HER2/neu oncogene driven by the MMTV promoter [16]. The mutated gene encodes a single point mutation that replaces the valine residue at position 664 in the transmembrane (TM) domain of $\mathrm{p} 185 /$ neu with glutamic acid. This mutation promotes $\mathrm{p} 185 /$ neu homo- and heterodimerization and transforms the HER2/neu protooncogene into a dominant transforming oncogene. In these studies animals were used for tissue harvest only. Nonetheless, all animal research was conducted following an approved protocol filed with the Animal Investigation Committee at Wayne State University that oversees the Division of Laboratory Animal Resources (DLAR) at this institution in strict accordance with NIH guidelines.

\section{Iressa ${ }^{\mathrm{TM}}$ and cell lines}

"Iressa" ${ }^{\mathrm{Tm} " ~(Z e n e c a ~ P h a r m a c e u t i c a l s ~ M a c c l e s f i e l d, ~ C h e s h-~}$ ire) ZD1839, 4-(3-chloro-4-fluoroanilino)-7-methoxy-6(3-morpholinopropoxy) quinazoline was suspended in DMSO at $10 \mathrm{mM}$ and stored at $-20^{\circ} \mathrm{C}$ until use. Dilutions were prepared in culture medium to make final concentrations ranging from $0.25-10 \mu \mathrm{M}$. The Bam1a cell line has been previously described and characterized [6].

\section{Establishment and Maintenance of the MAM-I co-culture Model}

The MAM-1 co-culture model was established from a BALB-NeuT transgenic mouse with an advanced mammary gland lobular carcinoma involved with hemorrhage. The tissue was removed asceptically and rinsed extensively in sterile PBS. The tissue was minced and dissociated briefly with collagenase. Cells were washed extensively with complete medium and explanted into tissue culture media. Cultures grew in an organization of tumor cell nests surrounded by myofibroblasts and maintained a consistent 1:1 ratio of tumor cells to stromal cells. These 


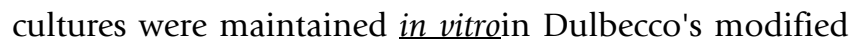
Eagle's medium (DMEM) with high glucose and supplemented with $10 \%$ heat inactivated Serum Supreme (BioWhittaker, St. Louis, MO), $0.5 \mathrm{mM}$ sodium pyruvate, 2 $\mathrm{mM}$ L-glutamate, $0.1 \mathrm{mM}$ MEM nonessential amino acids, $100 \mathrm{units} / \mathrm{ml}$ penicillin and $100 \mu \mathrm{g} / \mathrm{ml}$ streptomycin and $10 \mu \mathrm{M}$ Dexamethasone. Inclusion of dexamethasone, impairs the growth of contaminating fibroblasts and endothelial cells with limited proliferative and immortalization potential. Cells were cultured in $10 \% \mathrm{CO}_{2}$, media was changed every 3-4 days until confluence and split at a 1:5 ratio for routine passaging. -Co-cultures can be expected to maintain a $1: 1$ ratio during active growth. This ratio may be altered if cultures are kept beyond confluence when stromal cells continue to grow. At time of passage, the majority of stromal cells are collected separately by a brief trypsinization. The remaining co-culture is further trypsinized and monodispersed and collected separately. Both collections are counted by hemacytometer which readily allows for distinguishing between the tumor (small) and stromal (large) cells. If need be, the cell ratios can be readjusted to accommodate the desired 1:1 ratio. All in vitro data presented in this manuscript used MAM-1 between passages 5-20.

\section{Immunohistochemistry}

At time of necropsy, tumor tissues were fixed in 10\% neutral buffered formalin and paraffin embedded using standard histochemical techniques. Blocks were sectioned 4-micron. Tissue sections were stained with Hematoxylin and Eosin for basic histological evaluation. For immunodetection of tissue antigens, histological grade primary antibodies were applied to the samples and incubated according to manufacturer's recommendation: HER2, PAD: Z4881, cat\# 08-1204 2 $2^{\text {nd }}$ Gen; PCNA, cat\# 08-1110 (Zymed, South San Francisco, CA), PCNA Ab-1 clone (PC10) cat\# MS-106-R7; Actin, Smooth Ab-1 (1A4) cat\# MS-113-R7 (Neomarkers, Fremont, CA). Samples were washed and labeled using the SuperPicTure ${ }^{\mathrm{TM}}$ Polymer Detection Kit, cat\#87-9263; Zymed), developed with DAB Substrate and counterstained with hematoxylin. Samples were evaluated using a Zeiss microscope and images were collected through a Sony 970 CCD camera interfaced with the MCID5+ imaging software package. Alternatively images were collected using a Nikon inverted microscope equipped with a SPOT digital cooled camera and imaging software. Stained sections were evaluated by a board certified pathologist to generate descriptions.

\section{Flow cytometric analysis of MAM-I co-cultures}

A variety of antibodies were used for flow cytometric analyses. Selection of antibody combinations was based on fixation, host species, avidity/affinity for specific epitopes and antigen density. Antibodies used in these studies included: antibody to the rat Her2/neu (Ab-9, clone B10, cat\# MS-326); erbB-2 (Ab-15, clone 3B5, cat\# MS-599, NeoMarkers, Fremont, CA). CD24 (M1/69) sc-19651-PE; CD29 (Integrin $\beta 1$ (HM $\beta 1-1)$ sc-19656-PE; p-c-Jun (Ser63)-PE (KM-1) sc-822-PE all from Santa Cruz Biotechnology, Santa Cruz, CA. Ready to use histological grade antibodies that were also used on formaldehyde fixed samples prepped for flow cytometry or immunofluorescence included: (HER2, PAD: Z4881, cat\# 08-1204 $2^{\text {nd }}$ Gen; PCNA, cat\# 08-1110 Zymed, South San Francisco, CA). or PCNA Ab-1 clone (PC10) cat\# MS-106-R7; Actin, Smooth Ab-1 (1A4) cat\# MS-113-R7 or cat\# RB-9010-R7, Neomarkers, Fremont, CA. Phospho-specific antibodies from Cell Signaling Technologies, (Beverly, MA) used in FACS and Immunofluorescence included: p-p44/42 MAP kinase (Thr202/Tyr204, \#9101), p-MEK 1/2 (Ser217/221. \#9121)

Routine cell surface staining of fresh cell cultures was as previously described [5]. For evaluation of intracellular antigens, MAM-1 were plated in 6 well tissue cultures plates to produce a confluent, organized co-culture $(1: 1$ tumor to stroma cell ratio) within 2-3 days of seeding. Cells were harvested at specific time points after treatment with trypsin/EDTA, quenched with complete medium and collected by centrifugation. Pellets were resuspended in $1 \mathrm{~mL}$ of PBS and monodispersed by passing through a small bore pipet. Cells were fixed by titrating in 5\% Formaldehyde to a final concentration of $1 \%$, incubated at $37^{\circ} \mathrm{C}$ for 10 minutes, then chilled on ice for 2 minutes. Absolute, ice-cold $\left(-20^{\circ} \mathrm{C}\right)$ methanol was added while vortexing to a final concentration of $90 \%$. Samples were vortexed rigorously and incubated on ice for 30 minutes. Cells were collected by centrifugation and blocked for 30 minutes on ice with chilled FACscan buffer (PBS supplemented with $2 \%$ serum and $0.1 \%$ sodium azide). Cells were washed once with fresh FACscan buffer prior to the addition of primary antibodies or isotype controls and stained overnight at $4{ }^{\circ} \mathrm{C}$ in accordance to the manufacture's guidelines. Cells were washed twice and stained with the appropriate -PE or -FITC conjugated secondary antibodies: goat anti-mouse IgG-PE, cat\# 111-116-144; donkey anti-rabbit IgG-FITC, cat\#711-096-152; donkey anti-mouse IgG-PE, cat\# 715-116-150 (Jackson ImmunoResearch, West Grove, PA) at 1:50 to 1:200 on ice for 45 min. After staining, samples were washed twice with FACscan buffer, placed on ice and evaluated by flow cytometry using the dual-color laser option (FL1 v. FL2) in the FACsCaliber. At least 20,000 events were collected for every sample. Data were analyzed using WinMDI version 2.8 software. Importantly, all experiments were reproduced at least three times using MAM-1 of different passage numbers and overlapping experimental treatments and time points. The specificities of all stains were validated by using various combinations of monoclonal and polyclonal antibodies for each antigen and different secondary 
labels. All phospho-specific markers and PCNA stains were evaluated by direct reciprocal dual-staining for the test antigen with in combination with antibodies to ErbB2 and $\alpha$-SMA to verify that all ErbB- 2 negative responses were identical to $\alpha$-SMA positive responses and vice versa.

\section{Immunofluorescence}

MAM-1 suspensions were plated on glass cover slips in 6 well plates in complete media and grown to $90-95 \%$ of confluence and treated as described in the text. Following treatment, cells were fixed and permeabilized by immersion in ice-cold $100 \%$ methanol and incubated at $-20^{\circ} \mathrm{C}$ for 10-20 min. Methanol was aspirated and cover slips were air-dried, washed and blocked prior to administration of primary antibodies. Primary antibodies were diluted and incubated on cover slips according to the recommendations for each specific antibody. Cover slips were washed 4 times before adding the secondary FITC- or TRITC-conjugated goat anti-mouse or rabbit IgG (cat\# 115-096-071, 111-096-046, 111-116-144 or 115-116071; Jackson ImmunoResearch, West Grove, PA) antibodies diluted 1:50-1:200 in FACscan buffer. Samples were incubated with secondary for $45 \mathrm{~min}$. at room temperature in the dark. Stained cover slips were washed and mounted in Fluorescent mounting media (cat\# HT08, Oncogene Science) containing DAPI for nuclear counterstaining. Slides were visualized at $100 \times$ under oil with a Zeiss microscope equipped with a Sony 970 digital cooled camera. Fluorescence photomicrographs were imaged using MCID5+ software. Live cell images and phase contrast of cells fixed in 6-well culture dishes were evaluated with a Nikon inverted microscope and imaged using the attached SPOT digital cooled camera and imaging software.

\section{Gene Expression Analysis}

Total RNA was isolated from triplicate wells of Bam1a cells [6] or MAM-1 co-cultures that were treated for $24 \mathrm{~h}$ with complete media containing 0 or $1 \mu \mathrm{M}$ Iressa. Total RNA was isolated using RNeasy kit (Qiagen, Carlsbad, $\mathrm{CA}$ ) and sent to SuperArray Bioscience Corporation (Frederick, MD) and processed utilizing the GEArray Hybridization and Analysis Service and Agilent Mouse Genome CGH Microarray 44A that has 43,000+ annotated gene sequences with well-characterized genes represented by $1+$ probes and cancer-relevant genes by $2+$ probes. In some comparisons Universal mouse RNA provided by Agilent was also used in the analyses for normalization. Three independent RNA preparations per condition were analyzed on three separate chips and used to generate the analysis report. To generate lists of highly expressed genes, RNA from MAM-1 was labeled in red color (cy5), universal RNA was labeled in green (cy3). 1) In ${ }^{* *}$ treated vs ** control comparison, the treated is labeled in red color (cy5), control is labeled in green color (cy3). Fold change $\left({ }^{* *}\right.$ treated $/{ }^{* *}$ control $)=$ Normalized ratio value $(\mathrm{cy} 5 /$ cy3); fold change cutoff $>2$ fold (up regulate) or $<1 / 2$ (down regulate); confidence cutoff $>0.95$.

\section{Results and Discussion Histological analysis of the primary tumor tissue used to derive MAM-I}

The tumor was obtained from a BALB-NeuT transgenic mouse bearing a lesion that involved a hemorrhage of the \#8 thoracic mammary gland. The pathology report describes the tumor as forming a discrete nodule, most of which is contained within a thin rim of collagen (pseudocapsule) with rare isolated acini penetrating it (Fig. 1A). The tumor is made of epithelial cells, arranged in illdefined nests that are separated by fine fibrous septa. Discrete acini, delimiting central lumens, and filled with lightly eosinophilic secretions, confer to these epithelial nests a distinct overall, sieve-like (cribriform) configuration. Necrotic material and focally hemorrhage, frequently accumulates within the tumor, in a punctate fashion (comedo-type necrosis). Tumor cells show homogenous cytological features and only mild pleomorphism (Fig. 1B). They are polygonal, with a relatively low N/C ratio, eosinophilic cytoplasm, round central nuclei with finely dispersed chromatin and infrequent macronucleoli and undergo frequent mitoses. This description is consistent with the morphology of the lobular carcinomas that arise in BALB-NeuT transgenic mice [16].

The sample of this lesion that was explanted and processed for growth in vitro, demonstrates a significant stromal cell component (Fig. 1). By immunohistochemistry we observed that HER2/neu staining was strong and present in the majority of the tumor cells (Fig. 1C), in a cytoplasmic and membranous distribution and that $\alpha$ SMA staining was strong and exclusively expressed in the cytoplasm of the stromal cells that were involved in the fibrous sheaths surrounding the tumor cell nests (Fig. 1D).

\section{Growth and maintenance of MAM-I explant cultures}

In mice transgenic for the activated rat HER2/neu under the MMTV promoter, expression of the oncogene in the mammary gland epithelium gives rise to an alveolar type of lobular carcinoma that requires an angiogenic switch for tumor onset and progression to invasive cancer [16]. Coordinated epithelial-stromal interactions that are required for mammary morphogenesis and development are also critical for tumor progression in this model. In the case of human breast cancers, stromal alterations are also integral to the evolution and progression of breast cancer $[17,18]$.

Preservation of the breast cancer microenvironment is critical for evaluating therapeutic agents especially when 


\section{Figure 1, Piechocki}

\section{X H\&E 40X H\&E}

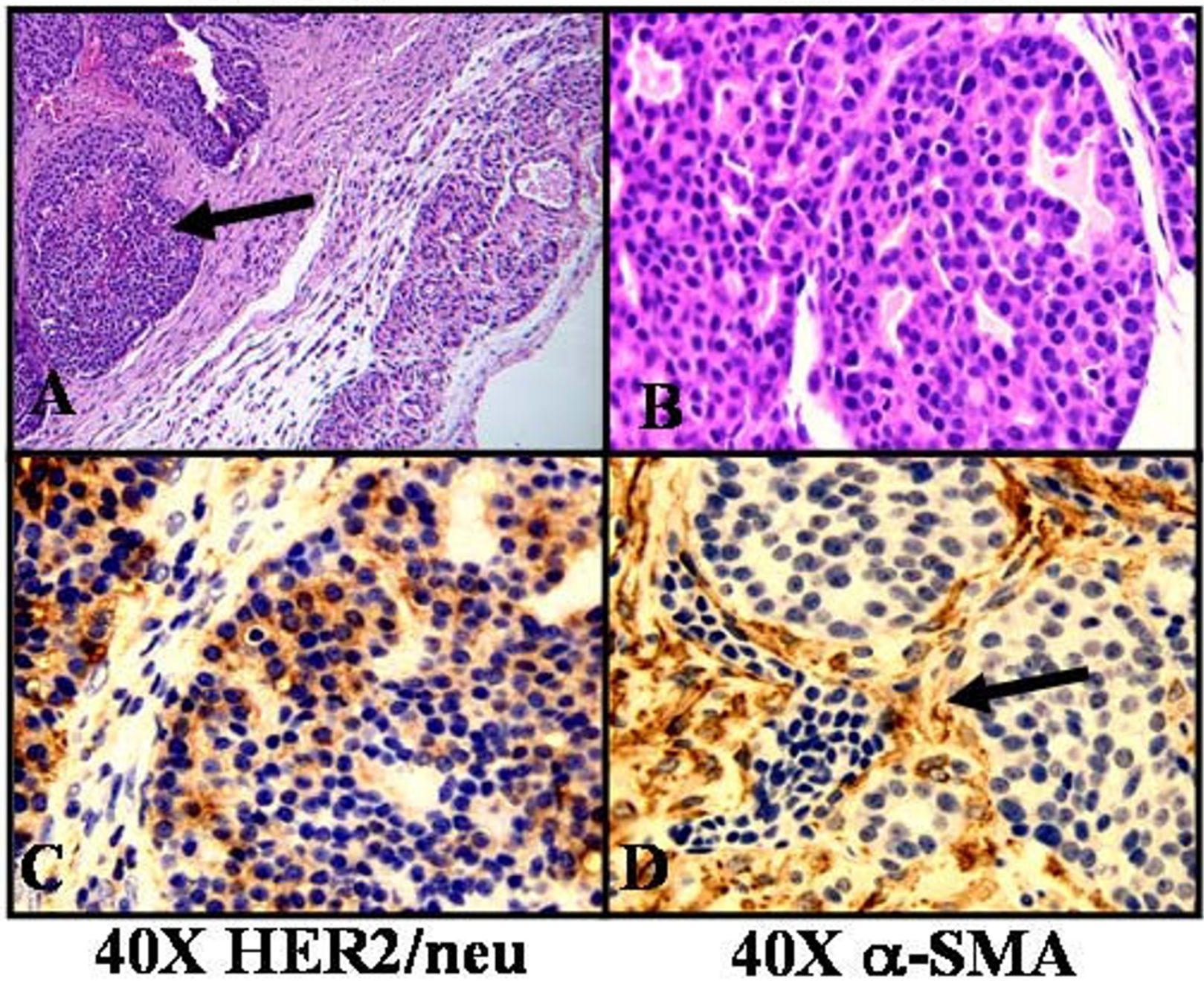

Figure I

Histological analysis of the primary tumor tissue used to derive MAM-I. The tumor was obtained from the \#8 mammary gland of a BALB-NeuT transgenic mouse. A. Hematoxylin and Eosin staining revealed a prominent fibrovascular response associated with the tumor (4x). The tumor forms a discrete nodule within a thin rim of collagen (pseudocapsule). The tumor is made of epithelial cells, arranged in ill-defined nests (arrow) that are separated by fine fibrous septa. Discrete acini, delimiting central lumens, and filled with lightly eosinophilic secretions, confer to these epithelial nests a distinct overall, sieve-like (cribriform) configuration. Necrotic material and focal hemorrhage accumulates within the tumor, in a punctate fashion (comedotype necrosis). B. Tumor cells show homogenous cytological features and only mild pleomorphism. They are polygonal, with a relatively low N/C ratio, eosinophilic cytoplasm, round central nuclei with finely dispersed chromatin and infrequent macronucleoli and undergo frequent mitoses (40x). C. Immunohistochemical analysis of HER2/neu shows strong staining in the majority of the tumor cells, in a cytoplasmic and membranous distribution. D. Immunohistochemical analysis for $\alpha$-SMA detected strong cytoplasmic staining associated exclusively with the stromal cells (arrow) surrounding the tumor cell nests. The antigens were detected by DAB (brown) and nuclei counterstained with hematoxylin (blue). Images were photographed under 40x objective. 
designing modalities that target invasive disease. Thus, we sought to establish a homotypic system representing invasive breast cancer by explanting the mammary tumor and associated stromal cells to develop a co-culture model. Upon explantation from the tumor, primary cultures that grew in vitro produced a co-culture that organized as multi-cell layered nests of tumor cells surrounded by concentric rings of stromal cells. These arrangements bear a striking similarity to the morphology of the primary tumor lesion (Fig. 2). This configuration was stable and was able to renew itself under limiting cell dilutions, these co-cultures were designated as MAM-1.

Passage of MAM-1 stock cultures at a 1:5 ratio maintained this organized growth pattern to reproducibly generate cocultures that consisted of 50\% tumor cells and 50\% stromal cells. Cultures maintained in this way achieved 95\% confluence within 5-7 days reproducibly for out to 20 passages. There was a tendency for stromal cells to proliferate more rapidly. Excess stromal cell growth was controlled by a mild trypsinization that released the superficial layer of stromal cells from the culture. At days 3-5 post-confluence, tumor cell nests formed spheroids that eventually pinched off and were capable of re-establishing the MAM-1 configuration when plated on fresh tissue culture plastic. Thus, spheroid formation is a natural progression in this co-culture model and does not require the elaborate procedures or growth conditions described for other model systems $[8,11,12]$. MAM-1 is also capable of growth in soft agar. However, if not in association with MAM-1 tumor cells, stromal cells will tend to form monolayers on top of or beneath the agar. One reason for the faithful renewal of this self-contained co-culture model can be attributed to the properties of syngeneic tumor associated stromal cells which have a strong influence on mammary tumor cell growth and gene expression $[8,11,18]$. Further studies are underway, to establish the genetic relationship between the cells of the stroma and tumor (i.e. karyotype analysis) and to determine the potential of each cell type to develop tumors in vivo.

\section{Validation of tumor specific and stroma specific antigens in explant cultures by Immunofluorescence and Flow cytometry}

As suggested by immunohistochemical analysis of the primary tumor (Fig. 1) we expected the tumor cells in these co-cultures to express HER2/neu and the stromal cells to express $\alpha$-SMA. We observed that expression of HER $2 /$ neu was exclusive to the tumor cell nests with a high level of distribution in the membrane and cytoplasm (Fig. 2). HER2/neu expression was at background level in the stromal cells, and $\alpha$-SMA was strongly expressed in the cytoplasmic actin-based microfilaments exclusively in these cells. In this co-culture setting, strong and consistent expression of both antigens, tumor-associated HER2/neu and stromal-associated $\alpha$-SMA were stable out to 20 passages. Using these two antigens as markers to identify and separate tumor from stroma cells, we adapted our staining method for flow cytometric analysis that would enable us to evaluate responses in each cell type.

As shown in Fig. 3A, the MAM-1 co-culture is readily fractionated into a HER2/neu+, $\alpha$-SMA-tumor subpopulation that accounts for $50-55 \%$ of the culture, a HER2-, $\alpha-$ $\mathrm{SMA}+$ stromal cell population that accounts for $40-45 \%$ of the culture, a HER2/neu+, $\alpha$-SMA+ population which may represent a stem cell or cells undergoing mesenchymal transition and typically accounts for 3-5\% of the culture and finally a double negative population that appears to represent a fibroblast population that typically accounts for $3-5 \%$ of the culture.

Whether or not a "true" mammary stem cell exists in this co-culture is under investigation. A variety of candidate mammary stem cell markers are expressed by the different subpopulations. In mature MAM-1 co-cultures we have determined that the tumor cell population is $\mathrm{HER} 2 / \mathrm{neu}^{+}$, CD24lo/med, CD29hi, SMA- and the stromal population is HER2/neu', CD24neg, CD29hi, SMA+. Since CD24 negative, lo and hi populations correspond to nonepithelial, basal/myoepithelial and luminal epithelial cells respective [19], we consider our "stromal" cells to be nonepithelial and our "tumor" cells to be a mixture of luminal and basal/myoepithelial phenotypes. In so much as CD $24+$ CD29hi phenotype is enriched in its ability to reconstitute the essential elements of the mammary gland, a mammary tumor stem cell-like subpopulation may be present in these MAM-1 cultures. Since the "oncogenic" activated rat HER2/neu genetic lesion is expressed in the mammary stem cell of the donor BALB-NeuT transgenic mice, it is possible that this co-culture model may support a limited degree of cell differentiation from a stem-like progenitor that is in the HER2/neu positive subpopulation. Further support for a stem cell component in this self-renewing co-culture model is provided by the high level of CD44 in MAM-1 and enriched expression of vimentin and cytokeratin 19 in MAM-1 compared to the cloned Bam1a cell line described later.

Using flow cytometric analysis we were able to further subfractionate the HER2/neu (tumor) population based on their Forward Scatter Profile, which is an index of cell size. These different size tumor cell subpopulations may represent cells enriched at different phases of the cell cycle, smaller cells tend to be enriched for cells in G0 and larger cells tend to be enriched for cells in G2/M (not shown). We typically observe an equal distribution of small (S) and large (L) cell subpopulations in the mammary tumor cell fraction (Fig. 3B). We observed that the larger cell population (L) had approximately >3-fold 


\section{Figure 2, Piechocki}
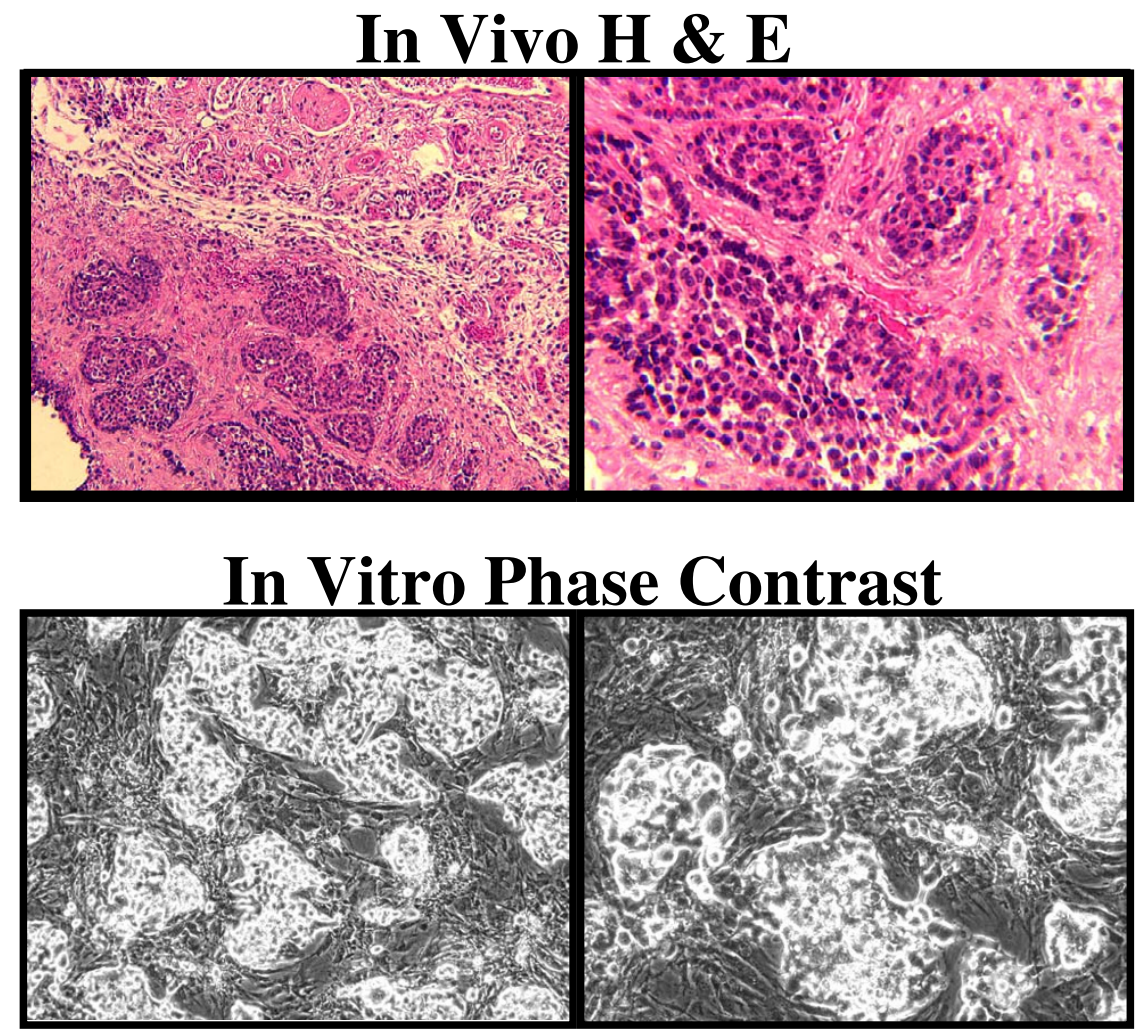

In Vitro Immunofluorescence

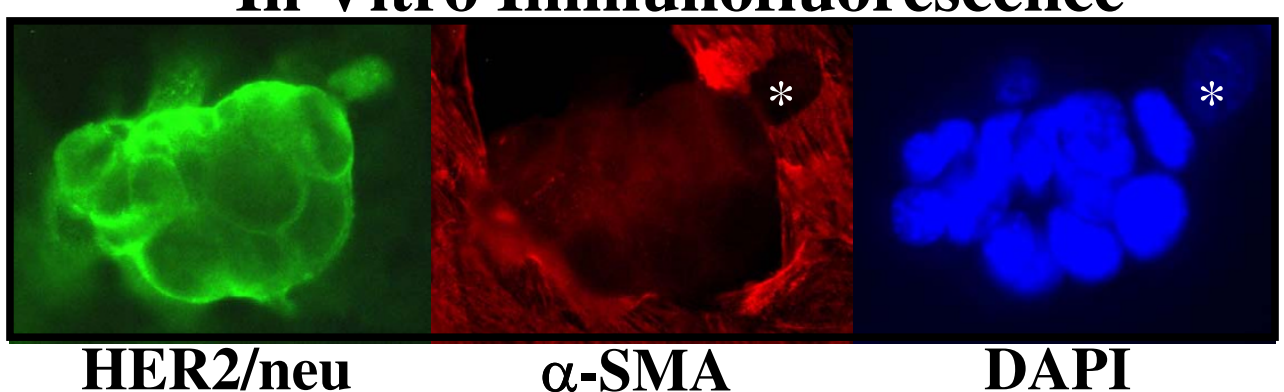

Figure 2

Comparison of Tumor tissue morphology in vivo with Explants grown in vitro. In Vivo H\&E (Top panel) is Hematoxylin and Eosin staining of the primary tumor lesion used for generating explant cultures and shows tumor cell nests in a fibrofatty matrix within the breast stroma taken with a 10× objective (left) and $25 \times$ objective (right). In Vitro Phase Contrast photomicrographs (Middle Panel) depict the growth and morphology of MAM-I explant cultures in vitro. Photomicrographs were taken with a (10x, left) or (20x, right) objective. Note in particular the morphological similarities between the explants grown in vitro and resemblance to the tumor in vivo. In Vitro Immunofluorescence (Bottom Panel) of MAM-I grown on coverslips and dual-stained for HER2/neu (FITC, green) and $\alpha$-SMA (TRITC, red) and counterstained for DAPI depicting the nuclei in blue. HER2/neu staining is strong and specific for tumor cells while $\alpha$-SMA staining is exclusively associated with the cells surrounding the tumor cell nests and localized to the actin-based cytoskeleton. Asterisk depicts nucleus of stromal cell for orientation. 
A

\author{
Figure 3, Piechocki
}
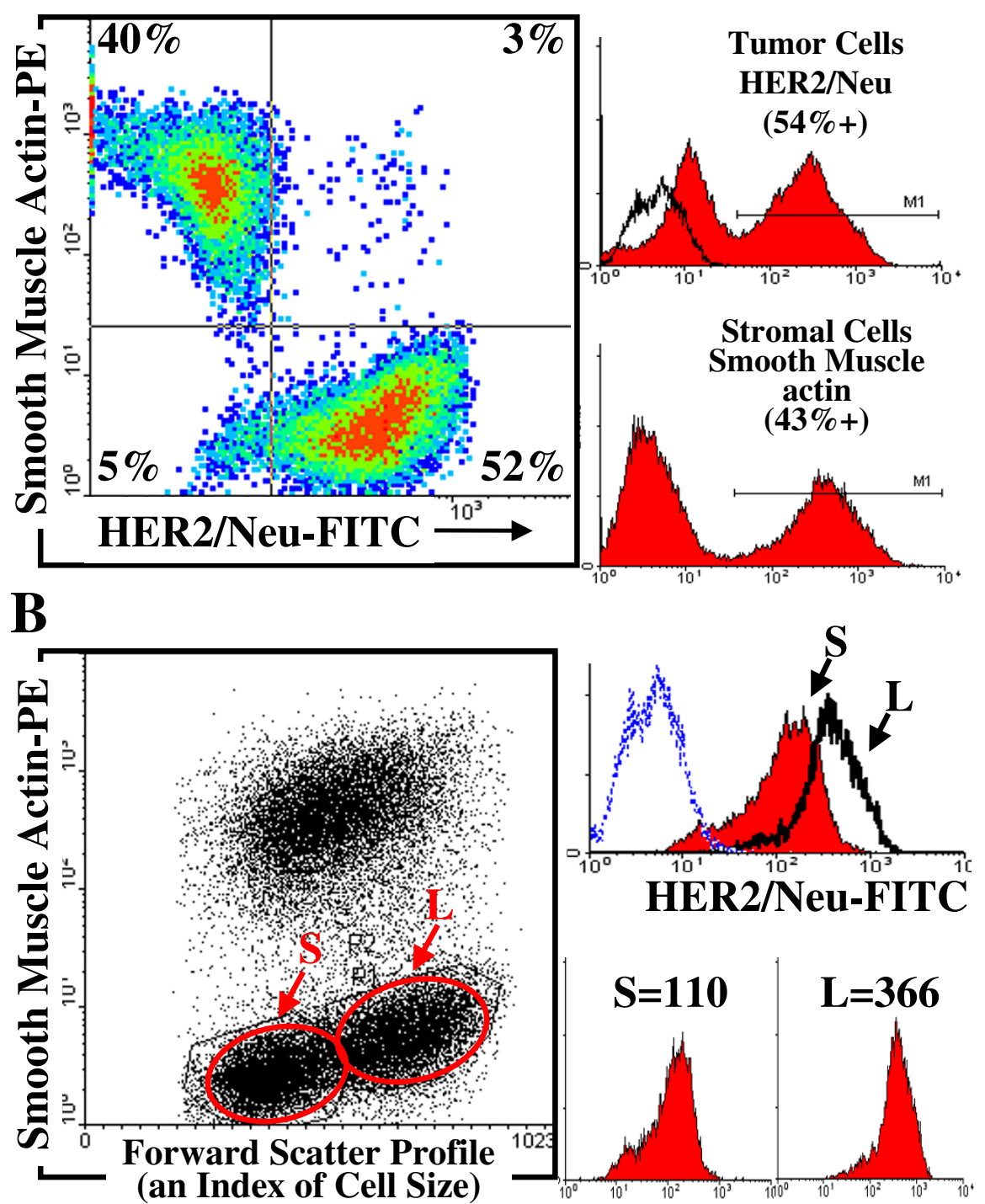

\title{
Figure 3
}

Flow Cytometric Analysis of MAM-I co-cultures. A. Density plot of MAM-I co-culture stained for HER2/neu and $\alpha$-SMA. MAM-I co-cultures were stained with the same ready-to-use, histological grade antibodies that were used for IHC and IC to detect HER2, PAD: Z488I and $\alpha$-SMA, (IA4) in tissues. Primary antibodies were labeled with -PE and FITC conjugated secondaries as described in the methods. Quadrant analysis revealed that MAM-I cultures consisted of $52 \%$ HER $2 /$ neu $^{+}, \alpha-S M A^{-}$tumor cells, $40 \%$ HER2/neu-, $\alpha-S^{-} A^{+}$stromal cells, a 5\% population of HER $2 /$ neu- $^{-}, \alpha-S M A^{-}$cells and a $3 \%$ population of HER2/neu ${ }^{+}, \alpha-S M A^{+}$cells which may represent cells undergoing epithelial-mesenchymal transition. At the right, Histogram analysis of the separate FLI (top) and FL2 (bottom) events indicates 54\% of the culture as positive for HER2/neu (top) and $43 \%$ of cells as positive for $\alpha$-SMA (bottom) which is consistent with the quadrant analysis. Filled peaks are specific antibody stained cells and open peaks represent background staining with the isotype control. B. Subpopulation analysis of Tumor cell fractions in MAM-I co-cultures based on Forward scatter profiles. Dot plot analysis of a-SMA-PE stained cells versus Forward scatter indicates the presence of two distinct subpopulations of different size in the a-SMA negative fraction labeled as $S$ (small) and $L$ (large). Histogram analysis of these gated subpopulations (defined by the circles) for HER2/neu specific staining indicates that the small population has lower levels of HER2/neu, a mean channel fluorescence of I I0 compared to the large population enriched in dividing cells, with a mean channel fluorescence of 366 . 
higher level of HER2/neu expression on the cell surface. If this subpopulation represents a high proportion of cells in G2/M antigens and drug responses that are differentially sensitive to the phase of cell cycle can be detected/ identified in the different sized tumor subpopulations (by forward scatter) and then confirmed and correlated with further analysis of the cell cycle distribution. For example, MAM-1 co-cultures that are treated for 1 hour with Iressa show a redistribution of p-c-Jun (Ser63) to the nucleus (Fig. 4A) and HER2/neu to the cytosol. In addition to redistribution from the cytosol, there was an overall decrease tumor cell associated phospho-c-Jun (i.e., in the $\alpha$-SMA negative cells) but not in the $\alpha$-SMA positive stromal cells (Fig. 4B). The observed $45 \%$ decrease in overall tumor cell phospho-c-Jun resulted from a $46 \%$ decrease that corresponded to the small cells and a $38 \%$ decrease in the large cells. Thus, small, non-dividing cells are about $20 \%$ more responsive to Iressa in terms of c-Jun phosphorylation. This further implies that large, dividing cells, which are enriched in HER2/neu receptors (Fig. 3B) and have a higher baseline level of phospho-c-Jun also have transient resistance to Iressa at this stage of the cell cycle. It has been widely documented that dividing cells often have a higher level of intrinsic resistance to a variety of chemotherapeutic agents.

\section{The MAM-I transcriptome has a genetic signature of ErbB-2 breast cancers and desmoplasia observed in invasive breast cancers}

We defined the MAM-1 transcriptome of highly expressed genes by comparing total RNA from a MAM-1 co-culture to a commercial preparation of universal mouse RNA which provides a balanced representation of normal and cancerous mouse tissues and cell lines. We used a cutoff value of $>2$-fold to be considered over-expressed and a $\mathrm{p}$ value cutoff $>.05$. A comprehensive listing of $>2,000$ known genes generated in this comparison is provided [see Additional file 1].

To identify genes associated with the tumor cell and stromal cell subpopulations in these cultures we compared the gene expression profiles of the Bam 1 a cell line, a cloned and characterized mammary carcinoma cell line developed from a BALB-NeuT mouse [6] and MAM-1 cocultures. Bam1a was established from a soft agar colony and found to be immortal in vitro and tumorigenic in vivo and highly sensitive to Iressa and anti HER2/neu antibodies both in vitro and in vivo [6]. We identified clusters of genes that were highly expressed and common to Bam1a and MAM-1 co-cultures or differentially expressed between Bam 1a and MAM-1. Table 1 is a representation of genes that are highly expressed by Bam $1 \mathrm{a}$ and MAM-1 and part of the "ErbB-2 Signature" that is associated with many ErbB-2 expressing breast cancers [20-23]. In most instances the relative expression level of these sig- nature genes was similar (within 2-fold) between Bam1a and MAM-1. This two-fold difference is likely to represent the dilution of tumor cell RNA with stromal cell RNA in the MAM-1 co-culture.

Genes uniquely over-expressed by MAM-1 largely reflect the stromal signature of this breast cancer co-culture system. A select list of 563 differentially expressed genes is provided [see Additional file 2]. We considered only differences greater than 3-fold to compensate for the dilution of tumor and stroma specific RNA in the MAM-1 cultures when compared to the cloned cell line, Bam1a. Certain genes that are uniquely over-expressed in Bam 1a are likely to reflect the influence of co-culture on the gene-expression patterns. Paradoxically, for example, we observe $>25$ fold higher expression of EPSTI1 in Bam1a compared to MAM-1, which contradicts what is typically observed and expected [12]. A majority of the genes that are overexpressed in MAM-1 have been identified in tumor associated fibroblasts and stromal cells and represent genes involved in the fibrotic response and basement membrane synthesis [24,25]. In particular, collagen genes involved in fibrosis and contraction and growth factors that stimulate the fibrotic response. In addition, genes involved in remodeling the extracellular matrix, including ADAM and MMP family members are highly represented.

When we compared genes differentially expressed between Bam1a and MAM-1 to genes clusters used to determine the stromal signatures of breast cancers, we found that relative to Bam 1a, MAM-1 over-expressed 70\% of the genes associated with the desmoid-type fibromatosis signature described by West et al. [24] including WISP2, COL1A1, COL5A1, COL3A1, COL6A1, MMP23, MMP19, CNN1, CTGF, ADAM19, FBN1 and ADAM12 (Table 2). This cluster of stroma specific genes, also identifies subgroups of breast carcinomas with a more favorable outcome when compared to the solitary fibrous tumor cluster [24] Further analyses revealed similarities between MAM-1 and an invasion specific cluster that is associated with the desmoplastic response to invading breast cancer [25] (Table 2). In particular, we observe $>20$-fold overexpression of COL1A1, IGFBP7 and SPARC in MAM-1 which are correlated with panstromal and juctatumoral stromal cell responses involved in matrix remodeling and angiogenesis, respective. These data are consistent with the histological features of the primary lesion used to establish MAM-1 and demonstrate the preserved expression of invasion specific genes in the MAM-1 co-culture. We also observed upregulation of a variety of stroma specific genes associated with tumor progression, invasion and the malignant phenotype in MAM-1. These include, MMP2 [10,18]ADAM12 [26], HAS2, [27] and CLIC4 $[28,29]$. Others have also demonstrated that heterologous co-cultures of breast tumor cells with tumor-derived 
A
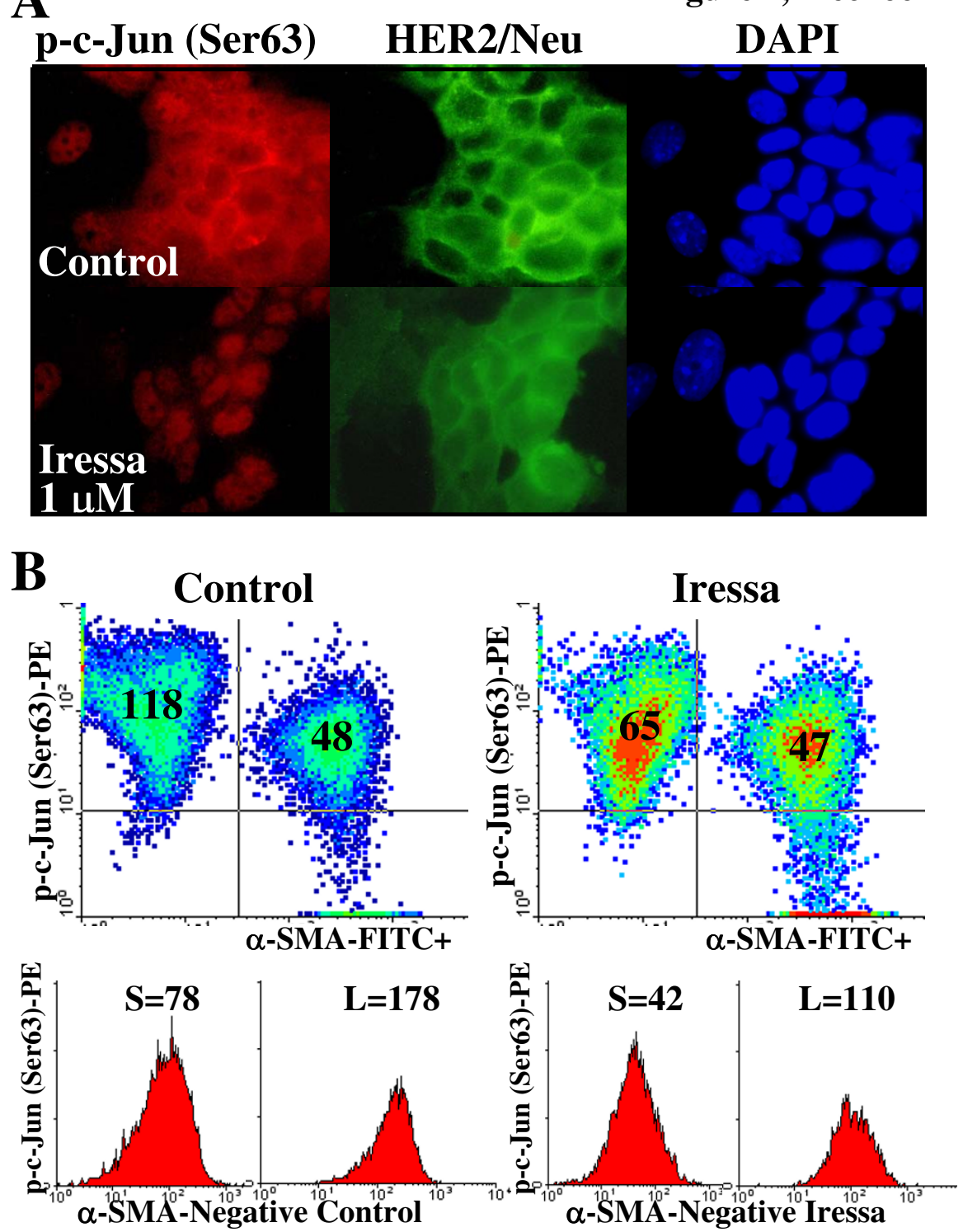

\section{Figure 4}

Evaluation of p-c-Jun (Ser63) levels and subcellular distribution in MAM-I co-cultures treated with Iressa by A. Immunofluorescence and B. Flow Cytometry. MAM-I were subcultured on coverslips or in 6-well plates and grown to $\sim 95 \%$ confluence and then treated by replacing the conditioned media with fresh media that contained diluent $(.001 \%$ DMSO, Control) or I $\mu \mathrm{M}$ Iressa for I hour prior to fixing and evaluation as described in the methods. A. Immunofluorescent photomicrographs were taken with the $100 \times$ objective under oil immersion of cells that were double labeled for p-c-Jun (Ser63) in red (TRITC) and HER2/neu in green (FITC) and counterstained with DAPI (blue) to define the nuclei. B. Flow cytometric analysis of control (left) and Iressa-treated (right) MAM-I cultures. Cells were dual labeled for p-c-Jun (Ser63) and $\alpha$-SMA. Density plots compare p-c-Jun (Ser63) expression levels in the $\alpha$-SMA negative and positive subpopulations in control and Iressatreated MAM-I cultures. Mean Channel fluorescent values for p-c-Jun (Ser63) are indicated in the respective quadrants. Histogram analyses for p-c-Jun (Ser63) expression in the $\alpha$-SMA negative subpopulations were generated from dot plots of p-Jun (Ser63)-PE versus Forward Scatter and gating on the respective the $S$ (small) and $L$ (large) fractions. Histograms of these tumor cell subpopulations demonstrate different baseline levels (Left) of p-c-Jun (Ser63) levels and Iressa responsiveness (Right) in small (S) and large (L) cells. Mean channel fluorescent values for p-c-Jun (Ser63) levels are indicated above the peaks. Parallel samples were dual stained for HER2/neu and p-c-Jun (Ser63) to verify these data (not shown). 
Table I: Expression of HER2/neu ErbB-2 Breast Cancer Signature genes in MAM-I Co-cultures and the Bam Ia cell line

\begin{tabular}{|c|c|c|c|c|}
\hline \multicolumn{5}{|c|}{ Expression Relative to Universal Mouse RNAa } \\
\hline Agilent Accession & Genbank Accession & MAM & Bamla & Gene Description and Symbol \\
\hline \multicolumn{5}{|c|}{ Genes present in the tumor-specific HER-2/neu-Induced Gene Expression Signature described by Astolfi } \\
\hline A_5I_PI84886 & NM 011920 & 5.27 & 19.10 & $\begin{array}{l}\text { Mus musculus ATP-binding cassette, sub-family G (WHITE), member } \\
2 \text { (Abcg2), mRNA [NM 0I } 1920]\end{array}$ \\
\hline A_52_P336142 & NM 011920 & 4.90 & 17.77 & $\begin{array}{l}\text { Mus musculus ATP-binding cassette, sub-family G (WHITE), member } \\
2 \text { (Abcg2), mRNA [NM 0I I920] }\end{array}$ \\
\hline A_5I_P342567 & NM 031185 & 9.10 & 6.60 & $\begin{array}{l}\text { Mus musculus A kinase (PRKA) anchor protein (gravin) } 12 \text { (Akap I2), } \\
\text { mRNA [NM 03।|85] }\end{array}$ \\
\hline A_5I_P445I66 & NM 019959 & 11.89 & 17.02 & $\begin{array}{l}\text { Mus musculus } \mathrm{Clq} \text { and tumor necrosis factor related protein I } \\
(\mathrm{Clqtnfl}), \mathrm{mRNA}[\mathrm{NM} \text { 019959] }\end{array}$ \\
\hline A_5I_P455647 & NM 009801 & 7.56 & 9.21 & Mus musculus carbonic anhydrase 2 (Car2), mRNA [NM 00980I] \\
\hline A_5I_P303160 & NM 007482 & 14.32 & 23.23 & Mus musculus arginase I, liver (ArgI), mRNA [NM 007482] \\
\hline A_52_PI59232 & NM_011926 & 20.60 & 24.52 & $\begin{array}{l}\text { Mus musculus CEA-related cell adhesion molecule I (Ceacam I), } \\
\text { mRNA [NM } 011926]\end{array}$ \\
\hline A_5I_PI83446 & NM 001039185 & 10.69 & 12.16 & $\begin{array}{l}\text { Mus musculus CEA-related cell adhesion molecule I, mRNA (cDNA } \\
\text { clone MGC:18556 IMAGE: } 4218391 \text { ), complete cds [BC0|689|] }\end{array}$ \\
\hline A_5I_PI7I728 & NM 011926 & 9.77 & 12.34 & $\begin{array}{l}\text { Mus musculus CEA-related cell adhesion molecule I (Ceacam I), } \\
\text { mRNA [NM 0I1926] }\end{array}$ \\
\hline A_52_P240706 & NM 007543 & 23.70 & 31.29 & $\begin{array}{l}\text { Mus musculus CEA-related cell adhesion molecule } 2 \text { (Ceacam2), } \\
\text { mRNA [NM 007543] }\end{array}$ \\
\hline A_5I_P362066 & NM 007695 & 8.34 & 3.89 & Mus musculus chitinase 3-like I (Chi3II), mRNA [NM 007695] \\
\hline A_5I_P495049 & NM 009897 & 10.34 & 11.46 & $\begin{array}{l}\text { Mus musculus creatine kinase, mitochondrial I, ubiquitous }(\mathrm{Ckmt}) \text {, } \\
\text { mRNA [NM 009897] }\end{array}$ \\
\hline A_5I_P343309 & NM 009908 & 5.83 & 10.54 & $\begin{array}{l}\text { Mus musculus cytidine monophospho-N-acetylneuraminic acid } \\
\text { synthetase (Cmas), mRNA [NM 009908] }\end{array}$ \\
\hline A_52_PI97963 & NM 009936 & 7.33 & 10.23 & $\begin{array}{l}\text { Mus musculus procollagen, type IX, alpha } 3 \text { (Col9a3), mRNA } \\
{[\text { NM 009936] }}\end{array}$ \\
\hline A_52_P507877 & NM 007729 & 41.31 & 30.23 & $\begin{array}{l}\text { Mus musculus procollagen, type XI, alpha I (Coll la I), mRNA } \\
{[\text { NM 007729] }}\end{array}$ \\
\hline A_5I_P459477 & NM 007729 & 34.68 & 28.45 & $\begin{array}{l}\text { Mus musculus procollagen, type XI, alpha I (Coll la I), mRNA } \\
{\left[\begin{array}{ll}\text { NM } 007729\end{array}\right]}\end{array}$ \\
\hline A_5I_P227280 & NM 007786 & 53.04 & 56.89 & Mus musculus casein kappa (Csnk), mRNA [NM 007786] \\
\hline A_5I_P227275 & NM 007786 & 26.87 & 32.53 & Mus musculus casein kappa (Csnk), mRNA [NM 007786] \\
\hline A_52_P51078 & NM 00780I & 23.49 & 35.47 & Mus musculus cathepsin $\mathrm{H}$ (Ctsh), mRNA [NM 00780I] \\
\hline A_5I_P275976 & NM 010070 & & 3.24 & Mus musculus docking protein I (Dokl), mRNA [NM 0l0070] \\
\hline A_52_P366842 & NM 010070 & 2.49 & 4.94 & Mus musculus docking protein I (DokI), mRNA [NM 0l0070] \\
\hline A_5I_PI58037 & NM 013505 & 11.59 & 12.52 & Mus musculus desmocollin 2 (Dsc2), mRNA [NM 013505$]$ \\
\hline A_52_PI57I58 & NM 013505 & 42.42 & 46.62 & Mus musculus desmocollin 2 (Dsc2), mRNA [NM 013505] \\
\hline A_52_P252931 & NM 013505 & 107.26 & 265.33 & Mus musculus desmocollin 2 (Dsc2), mRNA [NM 0|3505] \\
\hline A_5I_P502614 & NM 026268 & 4.28 & 6.46 & $\begin{array}{l}\text { Mus musculus dual specificity phosphatase } 6 \text { (Dusp6), mRNA } \\
\text { [NM 026268] }\end{array}$ \\
\hline A_5I_P455866 & NM 010125 & 27.80 & 29.60 & Mus musculus E74-like factor 5 (Elf5), mRNA [NM 010125$]$ \\
\hline A_5I_P307979 & NM_007960 & & 2.46 & Mus musculus ets variant gene I (Etvl), mRNA [NM_007960] \\
\hline A_5I_P246166 & NM 007969 & 10.06 & 10.23 & $\begin{array}{l}\text { Mus musculus extracellular proteinase inhibitor (Expi), mRNA } \\
{\left[\begin{array}{ll}\text { NM 007969] }\end{array}\right.}\end{array}$ \\
\hline A_52_P329207 & NM 007969 & 13.14 & 12.84 & $\begin{array}{l}\text { Mus musculus extracellular proteinase inhibitor (Expi), mRNA } \\
\text { [NM 007969] }\end{array}$ \\
\hline A_5I_P329394 & NM 008034 & 6.64 & 8.48 & Mus musculus folate receptor I (adult) (Folrl), mRNA [NM 008034] \\
\hline A_52_P37779I & $\overline{N M 008557}$ & 30.34 & 40.63 & $\begin{array}{l}\text { Mus musculus FXYD domain-containing ion transport regulator } 3 \\
\text { (Fxyd3), mRNA [NM_008557] }\end{array}$ \\
\hline A_5I_P282538 & NM 008077 & 28.43 & 73.47 & $\begin{array}{l}\text { Mus musculus glutamic acid decarboxylase I (GadI), mRNA } \\
\text { [NM 008077] }\end{array}$ \\
\hline A_52_PI44310 & NM 008077 & 27.33 & 68.46 & $\begin{array}{l}\text { Mus musculus glutamic acid decarboxylase I (Gadl), mRNA } \\
\text { [NM 008077] }\end{array}$ \\
\hline A_5I_P486810 & NM 030677 & 13.90 & 14.97 & $\begin{array}{l}\text { Mus musculus glutathione peroxidase } 2 \text { (Gpx2), mRNA } \\
\text { [NM 030677] }\end{array}$ \\
\hline A_5I_P258409 & NM 010423 & 13.98 & 30.78 & $\begin{array}{l}\text { Mus musculus hairy/enhancer-of-split related with YRPW motif I } \\
\text { (Heyl), mRNA [NM } 010423 \text { ] }\end{array}$ \\
\hline A_5I_P365I52 & NM 010474 & 23.53 & 48.48 & $\begin{array}{l}\text { Mus musculus heparan sulfate (glucosamine) 3-O-sulfotransferase I } \\
(\mathrm{Hs} 3 \mathrm{st} \mathrm{I}), \mathrm{mRNA} \text { [NM 010474] }\end{array}$ \\
\hline A_52_P28I702 & NM 010518 & 2.12 & 3.08 & $\begin{array}{l}\text { Mus musculus insulin-like growth factor binding protein } 5 \text { (lgfbp5), } \\
\text { mRNA }\left[\begin{array}{ll}\mathrm{NM} 0 & 05 \mid 8]\end{array}\right.\end{array}$ \\
\hline A_5I_P204I53 & NM 010518 & 4.25 & 10.70 & $\begin{array}{l}\text { Mus musculus insulin-like growth factor binding protein } 5 \text { (Igfbp5), } \\
\text { mRNA [NM } 0105 \mid 8]\end{array}$ \\
\hline A_5I_P5I0I56 & NM 008491 & 9.56 & 10.11 & Mus musculus lipocalin 2 (Lcn2), mRNA [NM 008491] \\
\hline A_52_PI53864 & NM 010723 & 2.77 & 3.75 & Mus musculus LIM domain only 4 (Lmo4), mRNA [NM 010723$]$ \\
\hline A_5I_P394190 & NM 010723 & 3.05 & 4.24 & Mus musculus LIM domain only 4 (Lmo4), mRNA [NM 010723$]$ \\
\hline A_52_P4I5I68 & NM 019394 & 8.35 & 8.26 & $\begin{array}{l}\text { Mus musculus melanoma inhibitory activity I (Mia I), mRNA } \\
\text { [NM 019394] }\end{array}$ \\
\hline A_52_P4I5I67 & NM 019394 & 18.65 & 22.26 & $\begin{array}{l}\text { Mus musculus melanoma inhibitory activity I (Mial), mRNA } \\
\text { [NM 019394] }\end{array}$ \\
\hline A_52_PI74346 & NM_019394 & 7.84 & 8.15 & $\begin{array}{l}\text { Mus musculus melanoma inhibitory activity I (Mia I), mRNA } \\
\text { [NM 019394] }\end{array}$ \\
\hline
\end{tabular}


Table I: Expression of HER2/neu ErbB-2 Breast Cancer Signature genes in MAM-I Co-cultures and the Bam la cell line (Continued)

\begin{tabular}{|c|c|c|c|c|}
\hline A_51_P220062 & NM 008609 & 10.60 & 15.42 & $\begin{array}{l}\text { Mus musculus matrix metalloproteinase } 15 \text { (Mmp I5), mRNA } \\
{[\mathrm{NM} 008609]}\end{array}$ \\
\hline A_5I_PI39780 & NM 009402 & 6.81 & 7.64 & $\begin{array}{l}\text { Mus musculus peptidoglycan recognition protein I (Pglyrp I), mRNA } \\
{[\text { NM 009402] }}\end{array}$ \\
\hline A_5I_PI95958 & NM 009344 & 3.26 & 6.05 & $\begin{array}{l}\text { Mus musculus pleckstrin homology-like domain, family A, member I } \\
\text { (Phlda I), mRNA [NM 009344] }\end{array}$ \\
\hline A_52_P4|879| & NM 011254 & 15.11 & 16.38 & $\begin{array}{l}\text { Mus musculus retinol binding protein I, cellular (Rbp I), mRNA } \\
\text { [NM 0II254] }\end{array}$ \\
\hline A_5I_P423484 & NM 011254 & 8.26 & 7.45 & $\begin{array}{l}\text { Mus musculus retinol binding protein I, cellular (Rbpl), mRNA } \\
\text { [NM 0II254] }\end{array}$ \\
\hline A_52_PI97215 & NM 028777 & 2.76 & 4.29 & $\begin{array}{l}\text { Mus musculus SECI4-like I (S. cerevisiae) (Sec|4II), mRNA } \\
\text { [NM 028777] }\end{array}$ \\
\hline A_52_PI97223 & NM 028777 & 3.32 & 5.72 & $\begin{array}{l}\text { Mus musculus SECI4-like I (S. cerevisiae) (Sec|4II), mRNA } \\
\text { [NM 028777] }\end{array}$ \\
\hline A_5I_P268094 & NM 009255 & 22.21 & 38.32 & $\begin{array}{l}\text { Mus musculus serine (or cysteine) proteinase inhibitor, clade E, } \\
\text { member } 2 \text { (Serpine2), mRNA [NM 009255] }\end{array}$ \\
\hline A_52_P637988 & NM 009199 & 40.88 & 62.00 & $\begin{array}{l}\text { Mus musculus solute carrier family I (neuronal/epithelial high affinity } \\
\text { glutamate transporter, system Xag), member I (Slc la I), mRNA } \\
\text { [NM 009199] }\end{array}$ \\
\hline A_5I_PII 0759 & NM 009199 & 20.06 & 26.16 & $\begin{array}{l}\text { Mus musculus solute carrier family I (neuronal/epithelial high affinity } \\
\text { glutamate transporter, system Xag), member I (Slcla I), mRNA } \\
\text { [NM 009199] }\end{array}$ \\
\hline A_52_P426605 & NM_021301 & 23.10 & 30.57 & $\begin{array}{l}\text { Mus musculus solute carrier family } 15(\mathrm{H}+/ \text { peptide transporter), } \\
\text { member } 2 \text { (SIcl } 5 \mathrm{a} 2), \mathrm{mRNA}[\mathrm{NM} \text { 02I30I] }\end{array}$ \\
\hline A_5I_PI07362 & NM 007706 & 13.23 & 14.79 & $\begin{array}{l}\text { Mus musculus suppressor of cytokine signaling } 2 \text { (Socs2), mRNA } \\
\text { [NM 007706] }\end{array}$ \\
\hline A_5I_P346704 & $\underline{X M} \quad 128139$ & 10.67 & 11.19 & $\begin{array}{l}\text { Mus musculus SRY-box containing gene 10, mRNA (cDNA clone } \\
\text { MGC:32314 IMAGE:502721 I), complete cds. [BC023356] }\end{array}$ \\
\hline A_52_PI92625 & XM 128139 & 23.80 & 36.33 & $\begin{array}{l}\text { Mus musculus SRY-box containing gene 10, mRNA (cDNA clone } \\
\text { MGC:32314 IMAGE:502721 I), complete cds. [BC023356] }\end{array}$ \\
\hline A_52_PI6I630 & NM 145933 & & 4.23 & $\begin{array}{l}\text { Mus musculus beta galactoside alpha } 2,6 \text { sialyltransferase I (St6gall), } \\
\text { mRNA [NM | } 45933 \text { ] }\end{array}$ \\
\hline A_5I_PI0I375 & NM 145933 & 2.35 & 5.29 & $\begin{array}{l}\text { Mus musculus beta galactoside alpha } 2,6 \text { sialyltransferase I (St6gal I), } \\
\text { mRNA [NM_145933] }\end{array}$ \\
\hline A_5I_PI83940 & NM 016866 & 2.21 & 3.02 & $\begin{array}{l}\text { Mus musculus serine/threonine kinase 39, STE20/SPSI homolog } \\
\text { (yeast) (Stk39), mRNA [NM 016866] }\end{array}$ \\
\hline A_52_P447944 & NM 008532 & 5.04 & 8.96 & $\begin{array}{l}\text { Mus musculus tumor-associated calcium signal transducer I } \\
\text { (TacstdI), mRNA [NM 008532] }\end{array}$ \\
\hline A_5I_P4I8820 & NM 009335 & 40.16 & 37.90 & $\begin{array}{l}\text { Mus musculus transcription factor AP-2, gamma (Tcfap2c), mRNA } \\
\text { [NM 009335] }\end{array}$ \\
\hline A_51_P338262 & NM_011619 & 5.37 & 8.17 & Mus musculus troponin T2, cardiac (Tnnt2), mRNA [NM_01/619] \\
\hline A_51_P482503 & NM 009413 & 21.46 & 34.02 & $\begin{array}{l}\text { Mus musculus tumor protein D52-like I (Tpd521I), mRNA } \\
{[\text { NM 0094I3] }}\end{array}$ \\
\hline A_5I_P506822 & NM 011674 & 42.90 & 81.82 & $\begin{array}{l}\text { Mus musculus UDP galactosyltransferase 8A (Ugt8a), mRNA } \\
{[\underline{\mathrm{NM}} \text { 011674] }}\end{array}$ \\
\hline A_52_P439263 & NM 011674 & 56.91 & 70.50 & $\begin{array}{l}\text { Mus musculus UDP galactosyltransferase 8A (Ugt8a), mRNA } \\
\text { [NM } 011674]\end{array}$ \\
\hline
\end{tabular}

Genes expressed in common with the mouse orthologs of the human "intrinsic" gene list of published by Sorlie

\begin{tabular}{|c|c|c|c|c|}
\hline A_5I_P3II 038 & NM 001024139 & 7.11 & 9.21 & $\begin{array}{l}\text { Mus musculus a disintegrin-like and metalloprotease (reprolysin type) } \\
\text { with thrombospondin type I motif, I } 5 \text { (Adamts I5), mRNA } \\
{[\text { [NM 001024I39] }}\end{array}$ \\
\hline A_5I_P3668II & NM 007470 & 45.17 & 36.20 & Mus musculus apolipoprotein D (Apod), mRNA [NM 007470] \\
\hline A_5I_PI630I5 & NM 172309 & 2.77 & 14.02 & $\begin{array}{l}\text { Mus musculus aryl hydrocarbon receptor nuclear translocator-like } 2 \\
\text { (Arnt|2), mRNA [NM 172309] }\end{array}$ \\
\hline A_5I_P455647 & NM_009801 & 7.57 & 9.21 & Mus musculus carbonic anhydrase 2 (Car2), mRNA [NM_00980I] \\
\hline A_5I_P302823 & NM 019686 & 4.02 & 11.39 & $\begin{array}{l}\text { Mus musculus calcium and integrin binding family member } 2 \text { (Cib2), } \\
\text { mRNA [NM 019686] }\end{array}$ \\
\hline A_5I_PI65I85 & NM 016887 & 11.54 & 15.50 & Mus musculus claudin 7 (Cldn7), mRNA [NM 016887] \\
\hline A_52_P507877 & NM 007729 & 41.32 & 30.23 & $\begin{array}{l}\text { Mus musculus procollagen, type XI, alpha I (Coll la I), mRNA } \\
{[\text { NM 007729] }}\end{array}$ \\
\hline A_5I_P459477 & NM 007729 & 34.69 & 28.45 & $\begin{array}{l}\text { Mus musculus procollagen, type XI, alpha I (Coll la I), mRNA } \\
\text { [NM_007729] }\end{array}$ \\
\hline A_5I_P5026I4 & NM 026268 & 4.28 & 6.46 & $\begin{array}{l}\text { Mus musculus dual specificity phosphatase } 6 \text { (Dusp6), mRNA } \\
\text { [NM 026268] }\end{array}$ \\
\hline A_5I_PII 6940 & $\underline{N M \quad 007940}$ & 15.92 & 5.95 & $\begin{array}{l}\text { Mus musculus epoxide hydrolase } 2 \text {, cytoplasmic }(\text { Ephx2), mRNA } \\
{[\text { NM 007940] }}\end{array}$ \\
\hline A_5I_P455932 & NM 007974 & 12.81 & 33.87 & $\begin{array}{l}\text { Mus musculus coagulation factor II (thrombin) receptor-like I (F2rlI), } \\
\text { mRNA [NM 007974] }\end{array}$ \\
\hline A_52_PI924I8 & NM 010175 & 2.63 & 4.90 & $\begin{array}{l}\text { Mus musculus Fas (TNFRSF6)-associated via death domain (Fadd), } \\
\text { mRNA [NM } 010175]\end{array}$ \\
\hline A_5I_P382925 & NM 010175 & 2.16 & 3.61 & $\begin{array}{l}\text { Mus musculus Fas (TNFRSF6)-associated via death domain (Fadd), } \\
\text { mRNA [NM } 010175]\end{array}$ \\
\hline A_52_PI00252 & NM 007988 & 3.23 & 3.40 & $\begin{array}{l}\text { Mus musculus clone:A630082H08 product:fatty acid synthase, full } \\
\text { insert sequence. [AK080374] }\end{array}$ \\
\hline A_52_PI36I62 & NM 010206 & 2.27 & 4.37 & $\begin{array}{l}\text { Mus musculus fibroblast growth factor receptor I (Fgfrl), mRNA } \\
\text { [NM_010206] }\end{array}$ \\
\hline
\end{tabular}


Table I: Expression of HER2/neu ErbB-2 Breast Cancer Signature genes in MAM-I Co-cultures and the Bam la cell line (Continued)

\begin{tabular}{|c|c|c|c|c|}
\hline A_52_P668810 & NM 010206 & & 3.81 & $\begin{array}{l}\text { Mus musculus fibroblast growth factor receptor I (Fgfrl), mRNA } \\
{[\mathrm{NM} 010206]}\end{array}$ \\
\hline A_5I_P335000 & NM 010211 & & 5.05 & $\begin{array}{l}\text { Mus musculus four and a half LIM domains I (FhlI), mRNA } \\
{[\mathrm{NM} 010211]}\end{array}$ \\
\hline A_5I_P329394 & NM 008034 & 6.64 & 8.48 & Mus musculus folate receptor I (adult) (Folrl), mRNA [NM 008034] \\
\hline A_52_P217710 & NM 008056 & & 3.08 & $\begin{array}{l}\text { Mus musculus frizzled homolog } 6 \text { (Drosophila) (Fzd6), mRNA } \\
\text { [NM 008056] }\end{array}$ \\
\hline A_51_P282538 & NM 008077 & 28.43 & 73.47 & $\begin{array}{l}\text { Mus musculus glutamic acid decarboxylase I (Gadl), mRNA } \\
\text { [NM 008077] }\end{array}$ \\
\hline A_52_PI44310 & NM 008077 & 27.33 & 68.46 & $\begin{array}{l}\text { Mus musculus glutamic acid decarboxylase I (Gad I), mRNA } \\
\text { [NM 008077] }\end{array}$ \\
\hline A_5I_P380005 & NM 015736 & 32.95 & 69.29 & $\begin{array}{l}\text { Mus musculus UDP-N-acetyl-alpha-D-galactosamine:polypeptide N- } \\
\text { acetylgalactosaminyltransferase } 3 \text { (Galnt3), mRNA [NM 015736] }\end{array}$ \\
\hline A_5I_P379997 & NM 015736 & 38.50 & 82.09 & $\begin{array}{l}\text { Mus musculus UDP-N-acetyl-alpha-D-galactosamine:polypeptide N- } \\
\text { acetylgalactosaminyltransferase } 3 \text { (Galnt3), mRNA [NM 015736] }\end{array}$ \\
\hline A_5I_P462422 & NM 008124 & & 5.07 & $\begin{array}{l}\text { Mus musculus gap junction membrane channel protein beta I (Gjbl), } \\
\text { mRNA [NM 008I24] }\end{array}$ \\
\hline A_52_PI64I9 & NM 01027I & 2.43 & 6.66 & $\begin{array}{l}\text { Mus musculus glycerol-3-phosphate dehydrogenase I (soluble) } \\
\text { (Gpdl), mRNA [NM 01027I] }\end{array}$ \\
\hline A_52_P4I5996 & NM_008184 & & 6.29 & $\begin{array}{l}\text { Mus musculus glutathione S-transferase, mu } 6 \text { (Gstm6), mRNA } \\
\text { [NM 008184] }\end{array}$ \\
\hline A_5I_PI79664 & NM 008185 & 3.67 & 6.80 & $\begin{array}{l}\text { Mus musculus glutathione S-transferase, theta I (Gsttl), mRNA } \\
\text { [NM 008185] }\end{array}$ \\
\hline A_52_P28I702 & NM 010518 & 2.12 & 3.08 & $\begin{array}{l}\text { Mus musculus insulin-like growth factor binding protein } 5 \text { (lgfbp5), } \\
\text { mRNA [NM } 010518]\end{array}$ \\
\hline A_5I_P204I53 & NM 010518 & 4.25 & 10.70 & $\begin{array}{l}\text { Mus musculus insulin-like growth factor binding protein } 5 \text { (lgfbp5), } \\
\text { mRNA [NM } 010518]\end{array}$ \\
\hline A_52_P40I386 & NM 010593 & 3.74 & 5.28 & Mus musculus junction plakoglobin (Jup), mRNA [NM 010593] \\
\hline A_52_P642488 & NM 008430 & 24.28 & 26.37 & $\begin{array}{l}\text { Mus musculus potassium channel, subfamily K, member I (Kcnkl), } \\
\text { mRNA [NM 008430] }\end{array}$ \\
\hline A_5I_P307964 & NM 010662 & 3.11 & 6.39 & $\begin{array}{l}\text { Mus musculus keratin complex I, acidic, gene I3 (Krtl - I3), mRNA } \\
\text { [NM 0 10662] }\end{array}$ \\
\hline A_5I_P324814 & NM 010664 & 2.93 & 3.89 & $\begin{array}{l}\text { Mus musculus keratin complex I, acidic, gene I8 (Krtl-18), mRNA } \\
\text { [NM 010664] }\end{array}$ \\
\hline A_52_P4I0685 & NM 033073 & 12.42 & 14.59 & $\begin{array}{l}\text { Mus musculus keratin complex 2, basic, gene } 7 \text { (Krt2-7), mRNA } \\
\text { [NM 033073] }\end{array}$ \\
\hline A_5I_P242400 & NM 031170 & 2.56 & 3.75 & $\begin{array}{l}\text { Mus musculus keratin complex 2, basic, gene } 8(\mathrm{Krt2}-8) \text {, mRNA } \\
{[\mathrm{NM} 031170]}\end{array}$ \\
\hline A_5I_PI74943 & NM 008485 & 6.90 & 10.66 & Mus musculus laminin, gamma 2 (Lamc2), mRNA [NM 008485] \\
\hline A_5I_P220062 & NM 008609 & 10.60 & 15.42 & $\begin{array}{l}\text { Mus musculus matrix metalloproteinase I5 (Mmp I5), mRNA } \\
\text { [NM 008609] }\end{array}$ \\
\hline A_5I_P5I4085 & NM 013606 & 3.75 & 6.35 & $\begin{array}{l}\text { Mus musculus myxovirus (influenza virus) resistance } 2(\mathrm{Mx2}), \mathrm{mRNA} \\
{[\mathrm{NM} 013606]}\end{array}$ \\
\hline A_52_P608097 & NM 008756 & 17.70 & 41.15 & Mus musculus occludin (Ocln), mRNA [NM 008756] \\
\hline A_51_P486150 & NM 008756 & 10.05 & 12.72 & Mus musculus occludin (Ocln), mRNA [NM 008756] \\
\hline A_52_P458279 & NM 011169 & 15.09 & 21.23 & Mus musculus prolactin receptor (Prlr), mRNA [NM 0111169] \\
\hline A_5I_P248345 & NM 009334 & & 17.92 & $\begin{array}{l}\text { Mus musculus transcription factor AP-2 beta (Tcfap2b), transcript } \\
\text { variant I, mRNA [NM 009334] }\end{array}$ \\
\hline A_5I_P4|8820 & NM_009335 & 40.16 & 37.90 & $\begin{array}{l}\text { Mus musculus transcription factor AP-2, gamma (Tcfap2c), mRNA } \\
\text { [NM 009335] }\end{array}$ \\
\hline A_5I_P240614 & NM 008536 & 3.79 & 5.43 & $\begin{array}{l}\text { Mus musculus transmembrane } 4 \text { superfamily member I (Tm4sf }) \text {, } \\
\text { mRNA [NM 008536] }\end{array}$ \\
\hline A_5I_P482503 & NM 009413 & 21.46 & 34.02 & $\begin{array}{l}\text { Mus musculus tumor protein D52-like I (Tpd52II), mRNA } \\
{[\mathrm{NM} 0094 \mid 3]}\end{array}$ \\
\hline A_5I_P106059 & NM 009423 & 2.81 & 3.48 & $\begin{array}{l}\text { Mus musculus Tnf receptor associated factor } 4 \text { (Traf4), mRNA } \\
\text { [NM 009423] }\end{array}$ \\
\hline A_52_P78403 & NM 009423 & 2.90 & 5.78 & $\begin{array}{l}\text { Mus musculus Tnf receptor associated factor } 4 \text { (Traf4), mRNA } \\
\text { [NM 009423] }\end{array}$ \\
\hline
\end{tabular}

Genes expressed in common with the MMTV/neu mammary tumor gene signature described by Landis

\begin{tabular}{|c|c|c|c|c|}
\hline A_51_P320852 & NM 007657 & 2.52 & 7.50 & Mus musculus CD9 antigen (Cd9), mRNA [NM 007657] \\
\hline A_51_P242265 & NM 009950 & 2.45 & 4.36 & $\begin{array}{l}\text { Mus musculus CASP2 and RIPKI domain containing adaptor with } \\
\text { death domain (Cradd), mRNA [NM 009950] }\end{array}$ \\
\hline A_52_P559779 & NM 007883 & 17.30 & 22.26 & Mus musculus desmoglein 2 (Dsg2), mRNA [NM 007883] \\
\hline A_51_P249848 & NM 007883 & 11.40 & 13.77 & Mus musculus desmoglein 2 (Dsg2), mRNA [NM 007883] \\
\hline A_52_P88091 & NM 007883 & 22.00 & 38.20 & Mus musculus desmoglein 2 (Dsg2), mRNA [NM 007883] \\
\hline A_52_P601757 & NM 007883 & 76.45 & 101.83 & $\begin{array}{l}\text { Mus musculus desmoglein 2, mRNA (cDNA clone IMAGE:4036406), } \\
\text { partial cds [BC034056] }\end{array}$ \\
\hline A_5I_P5026I4 & NM 026268 & 4.28 & 6.46 & $\begin{array}{l}\text { Mus musculus dual specificity phosphatase } 6 \text { (Dusp6), mRNA } \\
{[\text { NM 026268] }}\end{array}$ \\
\hline A_5I_P246166 & NM 007969 & 10.06 & 10.23 & $\begin{array}{l}\text { Mus musculus extracellular proteinase inhibitor (Expi), mRNA } \\
\text { [NM 007969] }\end{array}$ \\
\hline A_52_P329207 & NM 007969 & 13.14 & 12.84 & $\begin{array}{l}\text { Mus musculus extracellular proteinase inhibitor (Expi), mRNA } \\
\text { [NM 007969] }\end{array}$ \\
\hline A_5I_P329394 & NM 008034 & 6.64 & 8.48 & Mus musculus folate receptor I (adult) (Folr I), mRNA [NM 008034] \\
\hline A_5I_P352303 & NM 011983 & 5.94 & 8.58 & $\begin{array}{l}\text { Mus musculus homer homolog } 2 \text { (Drosophila) (Homer2), mRNA } \\
\text { [NM 0II1983] }\end{array}$ \\
\hline
\end{tabular}


Table I: Expression of HER2/neu ErbB-2 Breast Cancer Signature genes in MAM-I Co-cultures and the Bam Ia cell line (Continued)

\begin{tabular}{lllll}
\hline A_52_P176573 & NM 011983 & 7.52 & 12.27 & $\begin{array}{l}\text { Mus musculus homer homolog 2 (Drosophila) (Homer2), mRNA } \\
\text { [NM 011983] }\end{array}$ \\
A_51_P510156 & NM 008491 & 9.56 & 10.11 & Mus musculus lipocalin 2 (Lcn2), mRNA [NM 008491] \\
A_52_P382785 & $\underline{\text { NM 033525 }}$ & 3.71 & 12.17 & Mus musculus nephronectin (Npnt), mRNA [NM 033525] \\
A_51_P289889 & $\underline{\text { NM 033525 }}$ & 3.57 & 9.38 & Mus musculus nephronectin (Npnt), mRNA [NM 033525] \\
A_52_P17556 & $\underline{\text { NM 134249 }}$ & 6.84 & 18.37 & $\begin{array}{l}\text { Mus musculus T-cell immunoglobulin and mucin domain containing 2 } \\
\text { (Timd2), mRNA [NM 134249] }\end{array}$ \\
A_51_P500906 & NM 134249 & 12.27 & 24.24 & $\begin{array}{l}\text { Mus musculus T-cell immunoglobulin and mucin domain containing 2 } \\
\text { (Timd2), mRNA [NM_134249] }\end{array}$ \\
A_51_P482503 & NM 009413 & 21.46 & 34.02 & $\begin{array}{l}\text { Mus musculus tumor protein D52-like I (Tpd521I), mRNA } \\
\text { [NM 009413] }\end{array}$
\end{tabular}

Expression of genes associated with the human HER2/neu chromosome $17 \mathrm{q}$ amplicon by Bertucci

\begin{tabular}{|c|c|c|c|c|}
\hline A_5I_P3I7I76 & NM 00997I & 12.40 & 13.05 & $\begin{array}{l}\text { Mus musculus colony stimulating factor } 3 \text { (granulocyte) (Csf3), } \\
\text { mRNA [NM 00997II] }\end{array}$ \\
\hline A_51_P216179 & NM 010152 & 4.71 & 8.69 & $\begin{array}{l}\text { Mus musculus v-erb-b2 erythroblastic leukemia viral oncogene } \\
\text { homolog 2, neuro/glioblastoma derived oncogene homolog (avian) } \\
\text { (Erbb2), transcript variant 2, mRNA [NM 010152] }\end{array}$ \\
\hline A_5I_P230382 & NM 008815 & 2.63 & 3.66 & $\begin{array}{l}\text { Mus musculus ets variant gene } 4 \text { (EIA enhancer binding protein, } \\
\text { EIAF) (Etv4), mRNA [NM 0088|5] }\end{array}$ \\
\hline A_5I_P368823 & NM 010346 & 3.09 & 4.64 & $\begin{array}{l}\text { Mus musculus growth factor receptor bound protein } 7 \text { (Grb7), } \\
\text { mRNA [NM 010346] }\end{array}$ \\
\hline A_52_P40I386 & NM 010593 & 3.74 & 5.28 & Mus musculus junction plakoglobin (Jup), mRNA [NM 010593] \\
\hline A_52_P567306 & NM 010688 & 2.95 & 4.98 & Mus musculus LIM and SH3 protein I (LaspI), mRNA [NM 010688] \\
\hline A_51_PI82462 & NM 010688 & 2.46 & 3.44 & Mus musculus LIM and SH3 protein I (LaspI), mRNA [NM 010688] \\
\hline A_5I_P387I23 & NM 011854 & 2.77 & 4.06 & $\begin{array}{l}\text { Mus musculus 2'-5' oligoadenylate synthetase-like } 2 \text { (Oasl2), mRNA } \\
{[\text { [NM 0II } 1854]}\end{array}$ \\
\hline
\end{tabular}

aAverage fold difference is the ratio ( $n=3$, $p$ value cutoff $>.05$ ) MAM-I or Bam la RNA to Universal Mouse RNA. RNA from MAM-I or Bam Ia was labeled in red color (cy5), universal RNA is labeled in green (cy3). Three independent RNA preparations per condition were analyzed on three separate chips and averaged; a confidence cutoff of $>0.95$ was used for the raw values of red/green before normalization. The fold change (**MAMI or Bam Ia/** Universal Mouse $)=$ Normalized ratio value(cy5/cy3). The MAM-I and Bam la transcriptomes include genes that are differentially increased relative to the Universal mouse RNA by at least 2 -fold.

fibroblasts (but not normal skin fibroblasts) was required for myofibroblast differentiation (i.e., expression of alpha-SMA) and resembled the advanced stages of desmoplastic carcinomas [11], similar to what we observe in the homotypic MAM-1 co-culture model. In these studies, expression of PMP22 was identified as a candidate gene in modulating tumor cell interactions with fibroblast. In MAM-1, PMP22 is upregulated approximately 15 -fold and thus, may also play a role in the MAM-1 model.

\section{Effect of Iressa on signal transduction in MAM-I}

Western blot and microarray analyses revealed differential expression of the HER2/neu and EGFR in the respective tumor and stroma fractions of MAM-1 co-cultures. HER2/ neu was exclusively expressed in the mammary tumor cell fraction and EGFR was approximately 8-fold higher in the stromal cell population. In so much as the EGFR is approximately 50-fold more sensitive to Iressa $\left(\mathrm{IC}_{50}>0.080 \mu \mathrm{M}\right)$ compared to the c-erbB-2 tyrosine kinase $\left(\mathrm{IC}_{50} \sim 3 \mu \mathrm{M}\right)$ in vitro, we anticipated that EGFR in the stromal cell population was a likely target for the inhibitory activities of Iressa. Indeed, it has been suggested that targeting tumor associated fibroblasts [30] and the stromal EGFR may be a viable approach for preventing tumor progression and impeding the angiogenic switch. It has been shown that Iressa can differentially modulate fibrosis in various models of injury and disease [31-33]. It is important to distinguish, that in most injury models, the fibroblasts that are targeted as effectors of fibrosis are normal stromal fibroblasts and not phenotypically similar to the cancer associated fibroblasts/myofibroblasts that represent the stromal cells in the MAM-1 model. We expected that the response to Iressa in the MAM-1 stromal cells could be effected by their intrinsic sensitivity to Iressa and the microenvironment. Thus, we used the MAM-1 coculture model to determine the selectivity and specificity of Iressa for the HER2/neu over-expressing mammary tumor cells versus the EGFR-expressing stromal cells by evaluating signal transduction downstream of these RTKs.

In MAM-1 co-cultures that are stimulated by replacing the culture medium, strong cytoplasmic expression of phosphorylated p44/42 MAPK is readily observed (Fig. 5A). Inclusion of $1 \mu \mathrm{M}$ Iressa eliminates this response. By flow cytometric analysis we determined the dose-response for p44/42 MAPK and pMEK1/2 in the ErbB-2+ (tumor cell) and ErbB-2-(stromal cell) subpopulations in MAM-1 cocultures. We observed a dose-dependent decrease in pp44/42 MAPK and pMEK1/2 phosphorylation in tumor cells with maximal decreases of $90 \%$ and $40 \%$, respective (Fig. 5B). We also observed a modest (38\%) decrease in stromal cell phospho-pp44/42 MAPK at all doses of Iressa but no effect of pMEK1/2 phosphorylation, suggesting a small inhibitory effect of Iressa on the EGFR in the stroma. 
Table 2: Differentially expressed Fibromatosis and Desmoplastic response genes in the MAM-I Transcriptome

\begin{tabular}{|c|c|c|c|c|c|}
\hline Agilent Accession & Genbank Accession & $\begin{array}{l}\text { Ratio of MAM-I } \\
\text { vs. Bam la }\end{array}$ & p-value $(n=3)$ & Gene Description and Symbol & Reference \\
\hline A_5I_PI62272 & NM_009524 & 5.95 & $2.58 \mathrm{E}-03$ & $\begin{array}{l}\text { Mus musculus wingless-related MMTV integration } \\
\text { site 5A (Wnt5a), mRNA [NM 009524] }\end{array}$ & West \\
\hline A_5I_P390804 & NM 016873 & 125.00 & 8.89E-06 & $\begin{array}{l}\text { Mus musculus WNTI inducible signaling pathway } \\
\text { protein } 2 \text { (Wisp2), mRNA [NM } 016873]\end{array}$ & West \\
\hline A_5I_P220343 & NM 018865 & 16.66 & $4.06 \mathrm{E}-06$ & $\begin{array}{l}\text { Mus musculus WNTI inducible signaling pathway } \\
\text { protein I (Wispl), mRNA [NM 018865] }\end{array}$ & West \\
\hline A_52_P6586II & NM 007742 & 19.92 & 4.09E-03 & $\begin{array}{l}\text { Mus musculus procollagen, type I, alpha I } \\
\text { (Collal), mRNA [NM 007742] }\end{array}$ & West, lacobuzio-Donahue \\
\hline A_52_P525107 & NM 007742 & 187.97 & I. $12 \mathrm{E}-05$ & $\begin{array}{l}\text { Mus musculus procollagen, type I, alpha I } \\
\text { (Collal), mRNA [NM 007742] }\end{array}$ & West, lacobuzio-Donahue \\
\hline A_5I_P377094 & NM 007742 & 37.17 & $9.02 \mathrm{E}-08$ & $\begin{array}{l}\text { Mus musculus procollagen, type I, alpha I } \\
\text { (Collal), mRNA [NM 007742] }\end{array}$ & West, lacobuzio-Donahue \\
\hline A_5I_P4I4637 & $\underline{N M \quad 015734}$ & 168.63 & $7.15 \mathrm{E}-06$ & $\begin{array}{l}\text { Mus musculus procollagen, type V, alpha I } \\
\text { (Col5aI), mRNA [NM 015734] }\end{array}$ & West \\
\hline A_52_P684242 & NM 009930 & 4.93 & $7.45 \mathrm{E}-05$ & $\begin{array}{l}\text { Mus musculus procollagen, type III, alpha I } \\
\text { (Col3al), mRNA [NM 009930] }\end{array}$ & West \\
\hline A_5I_P5I5605 & NM 009930 & 94.34 & I.67E-09 & $\begin{array}{l}\text { Mus musculus procollagen, type III, alpha I } \\
\text { (Col3al), mRNA [NM 009930] }\end{array}$ & West \\
\hline A_5I_P474496 & NM_009933 & 12.21 & $6.30 \mathrm{E}-08$ & $\begin{array}{l}\text { Mus musculus procollagen, type Vl, alpha I } \\
\text { (Col6al), mRNA [NM 009933] }\end{array}$ & West \\
\hline A_5I_P502I32 & NM 011985 & 7.69 & $1.96 \mathrm{E}-07$ & $\begin{array}{l}\text { Mus musculus matrix metalloproteinase } 23 \\
\text { (Mmp23), mRNA [NM 011985] }\end{array}$ & West \\
\hline A_5I_P269166 & NM 021412 & 13.33 & I.IIE-02 & $\begin{array}{l}\text { Mus musculus matrix metalloproteinase } 19 \\
\text { (Mmp/9), mRNA [NM } 021412 \text { ] }\end{array}$ & West \\
\hline A_5I_P293087 & NM 008606 & 4.76 & $7.12 \mathrm{E}-06$ & $\begin{array}{l}\text { Mus musculus matrix metalloproteinase II } \\
\text { (MmpII), mRNA [NM 008606] }\end{array}$ & West \\
\hline A_5I_P404077 & $\underline{N M 020510}$ & 3.45 & $3.09 \mathrm{E}-06$ & $\begin{array}{l}\text { Mus musculus frizzled homolog } 2 \text { (Drosophila) } \\
\text { (Fzd2), mRNA [NM 020510] }\end{array}$ & West \\
\hline A_52_P597634 & $\underline{N M \quad 021457}$ & 4.55 & $5.25 \mathrm{E}-07$ & $\begin{array}{l}\text { Mus musculus frizzled homolog I (Drosophila) } \\
\text { (FzdI), mRNA [NM 02|457] }\end{array}$ & West \\
\hline A_52_P22480I & $\underline{N M 007993}$ & 130.03 & I.47E-03 & $\begin{array}{l}\text { Mus musculus fibrillin I (Fbn I), mRNA } \\
\text { [NM 007993] }\end{array}$ & West \\
\hline A_5I_P467224 & NM 007993 & 240.38 & $8.77 \mathrm{E}-05$ & $\begin{array}{l}\text { Mus musculus fibrillin I (Fbn I), mRNA } \\
\text { [NM 007993] }\end{array}$ & West \\
\hline A_52_P220176 & NM 015814 & 20.88 & $3.70 \mathrm{E}-02$ & $\begin{array}{l}\text { Mus musculus dickkopf homolog } 3 \text { (Xenopus } \\
\text { laevis) (Dkk3), mRNA [NM 0I58|4] }\end{array}$ & West \\
\hline A_52_P489295 & NM 009621 & 4.22 & $2.72 \mathrm{E}-05$ & $\begin{array}{l}\text { Mus musculus a disintegrin-like and } \\
\text { metalloprotease (reprolysin type) with } \\
\text { thrombospondin type I motif, I (Adamts I), } \\
\text { mRNA [NM 00962I] }\end{array}$ & West \\
\hline A_52_P213932 & NM 009621 & 3.10 & $1.94 \mathrm{E}-05$ & $\begin{array}{l}\text { Mus musculus a disintegrin-like and } \\
\text { metalloprotease (reprolysin type) with } \\
\text { thrombospondin type I motif, I (Adamts I), } \\
\text { mRNA [NM 00962I] }\end{array}$ & West \\
\hline A_52_P280044 & NM 009616 & 16.21 & $1.63 \mathrm{E}-05$ & $\begin{array}{l}\text { Mus musculus a disintegrin and metalloproteinase } \\
\text { domain } 19 \text { (meltrin beta) (Adam 19), mRNA } \\
\text { [NM 009616] }\end{array}$ & West \\
\hline A_5I_P267447 & NM 009616 & 10.35 & $8.95 \mathrm{E}-04$ & $\begin{array}{l}\text { Mus musculus a disintegrin and metalloproteinase } \\
\text { domain } 19 \text { (meltrin beta) (Adam 19), mRNA } \\
\text { [NM 009616] }\end{array}$ & West \\
\hline A_52_P290457 & NM 007400 & 33.11 & $4.05 \mathrm{E}-03$ & $\begin{array}{l}\text { Mus musculus a disintegrin and metalloproteinase } \\
\text { domain } 12 \text { (meltrin alpha) (Adam I2), mRNA } \\
\text { [NM 007400] }\end{array}$ & West, Peduto \\
\hline A_5I_P5I0882 & NM 007400 & 9.35 & I.38E-03 & $\begin{array}{l}\text { Mus musculus a disintegrin and metalloproteinase } \\
\text { domain } 12 \text { (meltrin alpha) (Adam I2), mRNA } \\
\text { [NM 007400] }\end{array}$ & West, Peduto \\
\hline A_5I_P3508I7 & NM 009922 & 38.46 & I.29E-04 & $\begin{array}{l}\text { Mus musculus calponin I (CnnI), mRNA } \\
\text { [NM 009922] }\end{array}$ & West \\
\hline A_52_P599578 & NM 145575 & 1.24 & $1.03 \mathrm{E}-02$ & $\begin{array}{l}\text { Mus musculus caldesmon I (CaldI), mRNA } \\
\text { [NM 145575] }\end{array}$ & West \\
\hline A_5I_P357573 & NM_145575 & 1.25 & $3.07 \mathrm{E}-02$ & $\begin{array}{l}\text { Mus musculus caldesmon I (CaldI), mRNA } \\
{\left[\begin{array}{ll}\text { NM } 145575]\end{array}\right.}\end{array}$ & West \\
\hline A_5I_PI57042 & NM 010217 & 14.33 & I.7IE-04 & $\begin{array}{l}\text { Mus musculus connective tissue growth factor } \\
\text { (Ctgf), mRNA [NM } 010217]\end{array}$ & West \\
\hline A_5I_PI24748 & NM 009368 & 0.45 & $7.08 \mathrm{E}-04$ & $\begin{array}{l}\text { Mus musculus transforming growth factor, beta } 3 \\
\text { (Tgfb3), mRNA [NM 009368] }\end{array}$ & West \\
\hline A_5I_P2I 2754 & NM 009369 & 11.76 & I.54E-03 & $\begin{array}{l}\text { Mus musculus transforming growth factor, beta } \\
\text { induced (Tgfbi), mRNA [NM 009369] }\end{array}$ & lacobuzio-Donahue \\
\hline A_5I_P472292 & NM 008048 & 65.79 & $6.80 \mathrm{E}-09$ & $\begin{array}{l}\text { Mus musculus insulin-like growth factor binding } \\
\text { protein } 7 \text { (lgfbp7), mRNA [NM 008048] }\end{array}$ & lacobuzio-Donahue \\
\hline A_5I_PII030I & NM 009778 & 4.59 & $3.95 \mathrm{E}-05$ & $\begin{array}{l}\text { Mus musculus complement component } 3 \text { (C3), } \\
\text { mRNA [NM_009778] }\end{array}$ & lacobuzio-Donahue \\
\hline A_5I_P2I 8774 & NM 026418 & 2.74 & $9.21 \mathrm{E}-04$ & $\begin{array}{l}\text { Mus musculus regulator of G-protein signalling } 10 \\
(\text { Rgs } 10), \text { mRNA [NM 0264l8] }\end{array}$ & lacobuzio-Donahue \\
\hline A_5I_P224843 & NM 021278 & 2.84 & $2.24 \mathrm{E}-03$ & $\begin{array}{l}\text { Mus musculus thymosin, beta } 4, X \text { chromosome } \\
(T m s b 4 x), m R N A[N M 021278]\end{array}$ & lacobuzio-Donahue \\
\hline
\end{tabular}


Table 2: Differentially expressed Fibromatosis and Desmoplastic response genes in the MAM-I Transcriptome (Continued)

\begin{tabular}{|c|c|c|c|c|c|}
\hline A_5I_PIIIIIO & NM 133786 & 1.10 & $1.45 \mathrm{E}-01$ & $\begin{array}{l}\text { Mus musculus SMC4 structural maintenance of } \\
\text { chromosomes 4-like I (yeast) (Smc4II), mRNA } \\
\text { [NM 133786] }\end{array}$ & lacobuzio-Donahue \\
\hline A_52_PI01852 & NM 009242 & 27.25 & $1.90 \mathrm{E}-07$ & $\begin{array}{l}\text { Mus musculus secreted acidic cysteine rich } \\
\text { glycoprotein (Sparc), mRNA [NM 009242] }\end{array}$ & lacobuzio-Donahue \\
\hline A_5I_P43I087 & NM 009242 & 67.11 & $1.96 \mathrm{E}-08$ & $\begin{array}{l}\text { Mus musculus secreted acidic cysteine rich } \\
\text { glycoprotein (Sparc), mRNA [NM 009242] }\end{array}$ & lacobuzio-Donahue \\
\hline A_5I_P452876 & NM 021515 & 7.46 & $3.48 \mathrm{E}-06$ & $\begin{array}{l}\text { Mus musculus adenylate kinase I (AkI), mRNA } \\
{\left[\begin{array}{ll}\text { NM } 0215 \mid 5]\end{array}\right.}\end{array}$ & lacobuzio-Donahue \\
\hline A_5I_PI49562 & NM 009686 & 6.13 & $1.52 \mathrm{E}-04$ & $\begin{array}{l}\text { Mus musculus amyloid beta (A4) precursor } \\
\text { protein-binding, family B, member } 2 \text { (Apbb2), } \\
\text { mRNA [NM 009686] }\end{array}$ & lacobuzio-Donahue \\
\hline A_52_P49250 & NM 010152 & 0.86 & $4.40 \mathrm{E}-03$ & $\begin{array}{l}\text { Mus musculus v-erb-b2 erythroblastic leukemia } \\
\text { viral oncogene homolog } 2 \text {, neuro/glioblastoma } \\
\text { derived oncogene homolog (avian) (Erbb2), } \\
\text { transcript variant 2, mRNA [NM 010152] }\end{array}$ & lacobuzio-Donahue \\
\hline A_5I_P216179 & NM 010152 & 0.54 & $3.14 \mathrm{E}-03$ & $\begin{array}{l}\text { Mus musculus v-erb-b2 erythroblastic leukemia } \\
\text { viral oncogene homolog 2, neuro/glioblastoma } \\
\text { derived oncogene homolog (avian) (Erbb2), } \\
\text { transcript variant 2, mRNA [NM 010152] }\end{array}$ & lacobuzio-Donahue \\
\hline A_5I_P34I736 & NM 008610 & 2.74 & $1.93 \mathrm{E}-04$ & $\begin{array}{l}\text { Mus musculus matrix metalloproteinase } 2 \\
\text { (Mmp2), mRNA [NM 008610] }\end{array}$ & Wang, Singer \\
\hline A_5I_P258529 & NM 008885 & 15.77 & $3.73 \mathrm{E}-05$ & $\begin{array}{l}\text { Mus musculus peripheral myelin protein (Pmp22), } \\
\text { mRNA [NM 008885] }\end{array}$ & Kunz-Schughart \\
\hline A_5I_P213359 & NM 008216 & 23.70 & 1.46E-07 & $\begin{array}{l}\text { Mus musculus hyaluronan synthase } 2 \text { (Has2), } \\
\text { mRNA [NM 008216] }\end{array}$ & $\mathrm{Li}$ \\
\hline A_52_P582374 & NM 178825 & 0.04 & $5.59 \mathrm{E}-03$ & $\begin{array}{l}\text { Mus musculus epithelial stromal interaction I } \\
\text { (breast) (Epsti I), transcript variant b, mRNA } \\
\text { [NM 178825] }\end{array}$ & Gudjonsson \\
\hline A_5I_P376050 & NM_029495 & 0.03 & $2.78 \mathrm{E}-03$ & $\begin{array}{l}\text { Mus musculus epithelial stromal interaction I } \\
\text { (breast) (Epsti I), transcript variant a, mRNA } \\
\text { [NM 029495] }\end{array}$ & Gudjonsson \\
\hline A_5I_PI2768I & NM 013885 & 3.62 & $1.28 \mathrm{E}-07$ & $\begin{array}{l}\text { Mus musculus chloride intracellular channel } 4 \\
\text { (mitochondrial) (Clic4), mRNA [NM 013885] }\end{array}$ & Suh, Ronnov-Jessen \\
\hline A_5I_P392687 & NM 011701 & 25.000 & $5.47 \mathrm{E}-04$ & $\begin{array}{l}\text { Mus musculus vimentin (Vim), mRNA } \\
{[\text { NM 011701] }}\end{array}$ & \\
\hline A_52_P5647I & NM 007912 & 4.35 & $8.57 \mathrm{E}-06$ & $\begin{array}{l}\text { Mus musculus epidermal growth factor receptor } \\
\text { (Egfr), transcript variant 2, mRNA [NM 0079|2] }\end{array}$ & \\
\hline A_5I_P392242 & NM 007912 & 4.17 & I.10E-05 & $\begin{array}{l}\text { Mus musculus epidermal growth factor receptor } \\
\text { (Egfr), transcript variant 2, mRNA [NM 0079|2] }\end{array}$ & \\
\hline A_52_P674338 & NM 207655 & 7.14 & $1.90 \mathrm{E}-03$ & $\begin{array}{l}\text { Mus musculus epidermal growth factor receptor } \\
\text { (Egfr), transcript variant I, mRNA [NM 207655] }\end{array}$ & \\
\hline A_52_P106259 & NM 207655 & 11.56 & $2.06 \mathrm{E}-05$ & $\begin{array}{l}\text { Mus musculus epidermal growth factor receptor } \\
\text { (Egfr), transcript variant I, mRNA [NM 207655] }\end{array}$ & \\
\hline A_5I_P4I48I3 & NM 010153 & 0.61 & $3.13 \mathrm{E}-03$ & $\begin{array}{l}\text { Mus musculus v-erb-b2 erythroblastic leukemia } \\
\text { viral oncogene homolog } 3 \text { (avian) (Erbb3), mRNA } \\
\text { [NM 010153] }\end{array}$ & \\
\hline A_5I_P342050 & NM 010153 & 0.58 & $3.28 \mathrm{E}-02$ & $\begin{array}{l}\text { Mus musculus v-erb-b2 erythroblastic leukemia } \\
\text { viral oncogene homolog } 3 \text { (avian) (Erbb3), mRNA } \\
{\left[\begin{array}{lll}\text { NM } & 010153]\end{array}\right.}\end{array}$ & \\
\hline A_52_P420504 & NM_007392 & 17.18 & 7.97E-05 & $\begin{array}{l}\text { Mus musculus actin, alpha 2, smooth muscle, } \\
\text { aorta (Acta2), mRNA [NM 007392] }\end{array}$ & \\
\hline A_52_P210078 & NM 007392 & 101.94 & $6.74 \mathrm{E}-05$ & $\begin{array}{l}\text { Mus musculus actin, alpha 2, smooth muscle, } \\
\text { aorta (Acta2), mRNA [NM 007392] }\end{array}$ & \\
\hline A_5I_PI03396 & NM 016879 & 0.260 & 2.69E-04 & $\begin{array}{l}\text { Mus musculus keratin complex } 2 \text {, basic, gene } 18 \\
(\text { Krt2-18), mRNA [NM 016879] }\end{array}$ & \\
\hline A_5I_P356642 & NM 00847I & 5.550 & $7.53 \mathrm{E}-06$ & $\begin{array}{l}\text { Mus musculus keratin complex } \mathrm{I} \text {, acidic, gene } 19 \\
(\mathrm{Krtl}-19) \text {, mRNA [NM 00847/I] }\end{array}$ & \\
\hline A_5I_P482I 28 & NM 008469 & 2.760 & $3.01 E-04$ & $\begin{array}{l}\text { Mus musculus keratin complex } \mathrm{I} \text {, acidic, gene } 15 \\
\text { (Krtl-15), mRNA [NM 008469] }\end{array}$ & \\
\hline A_5I_PII8225 & NM 028078 & 0.028 & $7.55 \mathrm{E}-04$ & $\begin{array}{l}\text { Mus musculus junction adhesion molecule } 4 \\
\text { (Jam4), mRNA [NM_028078] }\end{array}$ & \\
\hline A_5I_P358354 & NM 023277 & 30.030 & $2.2 \mathrm{IE}-06$ & $\begin{array}{l}\text { Mus musculus junction adhesion molecule } 3 \\
\text { (Jam3), mRNA [NM 023277] }\end{array}$ & \\
\hline A_52_P374846 & NM 023844 & 19.120 & $9.97 \mathrm{E}-04$ & $\begin{array}{l}\text { Mus musculus junction adhesion molecule } 2 \\
\text { (Jam2), mRNA [NM 023844] }\end{array}$ & \\
\hline A_5I_P4|8375 & NM 023844 & 10.256 & $8.90 \mathrm{E}-04$ & $\begin{array}{l}\text { Mus musculus junction adhesion molecule } 2 \\
\text { (Jam2), mRNA [NM 023844] }\end{array}$ & \\
\hline A_52_P93974 & NM 021359 & 0.316 & $1.46 \mathrm{E}-02$ & $\begin{array}{l}\text { Mus musculus integrin beta } 6 \text { (Itgb6), mRNA } \\
{[N M \text { 021359] }}\end{array}$ & \\
\hline A_52_P45952I & NM 001005607 & 0.261 & $3.06 \mathrm{E}-05$ & $\begin{array}{l}\text { Mus musculus integrin beta } 4 \text { (Itgb4), transcript } \\
\text { variant } 3 \text {, mRNA [NM } 001005607]\end{array}$ & \\
\hline A_5I_P382970 & NM 133721 & 25.125 & 3.19E-02 & $\begin{array}{l}\text { Mus musculus integrin alpha } 9 \text { (Itga9), mRNA } \\
\text { [NM 13372I] }\end{array}$ & \\
\hline A_52_P4I 3034 & NM 008398 & 2.985 & $2.73 \mathrm{E}-02$ & $\begin{array}{l}\text { Mus musculus integrin alpha } 7 \text { (Itga7), mRNA } \\
\text { [NM_008398] }\end{array}$ & \\
\hline A_5I_PI8167I & NM 008398 & 3.401 & $4.7 \mid \mathrm{E}-03$ & $\begin{array}{l}\text { Mus musculus integrin alpha } 7 \text { (Itga7), mRNA } \\
\text { [NM 008398] }\end{array}$ & \\
\hline A_52_P364|40 & NM 010577 & 30.030 & $1.76 \mathrm{E}-06$ & $\begin{array}{l}\text { Mus musculus integrin alpha } 5 \text { (fibronectin } \\
\text { receptor alpha) (Itga5), mRNA [NM } 010577]\end{array}$ & \\
\hline A_52_P223495 & NM 010576 & 0.304 & $4.7 \mid \mathrm{E}-02$ & $\begin{array}{l}\text { Mus musculus integrin alpha } 4 \text { (Itga4), mRNA } \\
{[\text { NM 010576] }}\end{array}$ & \\
\hline
\end{tabular}


Table 2: Differentially expressed Fibromatosis and Desmoplastic response genes in the MAM-I Transcriptome (Continued)

\begin{tabular}{lllll}
\hline A_51_P515056 & $\underline{\text { NM 013565 }}$ & 0.316 & $9.78 E-05$ & $\begin{array}{l}\text { Mus musculus integrin alpha 3 (Itga3), mRNA } \\
\text { [NM 013565] }\end{array}$ \\
A_51_P230405 & $\underline{\text { NM 013565 }}$ & 0.260 & $5.62 E-05$ & $\begin{array}{l}\text { Mus musculus integrin alpha 3 (Itga3), mRNA } \\
\text { [NM_013565] }\end{array}$ \\
A_52_P612019 & $\underline{\text { NM 008396 }}$ & 3.300 & $3.55 E-02$ & $\begin{array}{l}\text { Mus musculus integrin alpha 2 (Itga2), mRNA } \\
\text { [NM 008396] }\end{array}$
\end{tabular}

\begin{abstract}
aAverage fold difference is the ratio $(n=3$, $p$ value cutoff $>.05)$ compares the expression levels of MAM-I RNA normalized to Universal Mouse RNA to Bam I a RNA normalized to Universal Mouse RNA. RNA from MAM-I or Bam la was labeled in red color (cy5), universal RNA is labeled in green (cy3). Three independent RNA preparations per condition were analyzed on three separate chips and averaged; a confidence cutoff of $>0.95$ was used for the raw values of red/green before normalization. The fold change (**MAM-I or Bam la/**Universal Mouse) $=$ Normalized ratio value(cy5/cy3). P-values are for the comparisons between the MAM-I and Bam la. The references associated with specific genes are indicated in the text of the manuscript.
\end{abstract}

To determine the long term impact of these effects on cell growth and survival we treated MAM-1 co-cultures with Iressa for longer periods of time.

\section{Treatment of MAM-I with Iressa generates a fibrotic response in vitro}

When treated for an extended period of time with Iressa, the morphology of the MAM-1 co-culture recapitulated a fibrotic response such that tumor cell nests and islands gradually eroded away and stromal cells increased in density forming multi-cell layer nests (Fig. 6A). Our primary observation was that the morphology and cellularity of the co-cultures was dramatically altered. Within $24 \mathrm{~h}$ of treatment with $1 \mu \mathrm{M}$ Iressa, there was a decrease in the cellularity of tumor cell nests and an increase in the cellularity and density of $\alpha$-SMA reactive material associated with the stromal cell layers (Fig. 6B). Decreased cellularity of the tumor cell nests is accompanied by significant tumor cell rounding and apoptosis as evidenced by nuclear fragmentation shown with DAPI staining (Fig 7A) as well as positivity for Annexin V binding and cleaved caspase 3 (not shown). In addition to apoptosis, when probed for PCNA, there was a marked reduction in tumor cell PCNA and robust staining of PCNA in the stromal cells (Fig. 7A). Basic flow cytometric evaluation of these cultures demonstrated a $44 \%$ reduction in the tumor cell population within $24 \mathrm{~h}$ of treatment with $1 \mu \mathrm{M}$ Iressa and a $>3$-fold increase in the stromal cell population when compared to control cultures (not shown). When we evaluated the PCNA, phospho-p44/42 MAPK and phospho-MEK1/2 levels in the ErbB-2 positive and ErbB-2 negative subpopulations we observed a $62 \%, 54 \%$ and $27 \%$ reductions in tumor cell PCNA, phospho-p44/42 MAPK and phosphoMEK1/2, respective (Fig 7B). Interestingly, the larger subpopulation of tumor cells in these treated co-cultures were approximately 2 -fold less responsive to Iressa in terms of PCNA and phospho-p44/42 MAPK levels attesting to the transient resistance afforded to cells likely in G2/M (not shown). In contrast to ErbB-2 positive tumor cells, ErbB-2 negative stromal cells had a robust increase in all of these proliferation markers following treatment with Iressa. PCNA levels increased by 205\%, phospho-p44/42 MAPK increased 219\% and phospho-pMEK1/2 increased by $279 \%$. These data are in agreement with our qualitative observations that used immunofluorescence to document the relative density of the tumor and stroma cell populations in the MAM-1 co-cultures (Fig. 6B). The resilience of the stromal cell population is not limited to EGFR antagonists. We have also observed that while both the tumor and stroma cells express comparable levels of the TRAIL death receptor DR5, only the tumor cells are sensitive to TRAIL-mediated apoptosis (data not shown). Thus, targeting the stroma to effectively "sterilize" the microenvironment and inhibit tumor growth and progression presents a major challenge.

\section{Gene expression analysis reveals a signature of the fibrotic response}

To generate a better understanding of the global response of MAM-1 to Iressa, we compared the gene expression profiles of MAM-1 co-cultures treated for $24 \mathrm{~h}$ with fresh media containing diluent or $1 \mu \mathrm{M}$ Iressa. We observed a strong upregulation of inflammatory genes involved in the fibrotic response, consistent with the morphology of the treated MAM-1 co-cultures (Fig. 6A). Interestingly, none of the genes that were modulated by Iressa in Bam $1 \mathrm{a}$ cells [6] were altered in MAM-1. We observed 2.5- to 6fold increases in the expression of genes associated with inflammatory, fibrotic, pathological processes that are observed in a variety of diseases [34-37]. Most notably, we observed increases in inflammatory genes, (C9, CCR7, TNFRS25, IL1F9, CCL22, TLR8, KLRA23, CLEC4N, CD22), cell adhesion genes, (COL4A3, SIGLEC5, LGALS12, CLDN5) growth factor signaling and transcription genes, (FGF22, CTGF, WNT8A, POU4F3, HEY1) proliferation and differentiation (CCNB3, MYB, TFF1, PROX1) and proteolysis genes (GZMK, TLL2, ADAM5, SERPINA1D).

\section{Conclusion}

Our data demonstrate the utility of the MAM-1 co-culture model in understanding the impact of the tumor microenvironment on the differential responses of invasive breast cancers and tumor associated myofibroblasts to chemotherapeutic agents and therapeutic modalities. Our data 


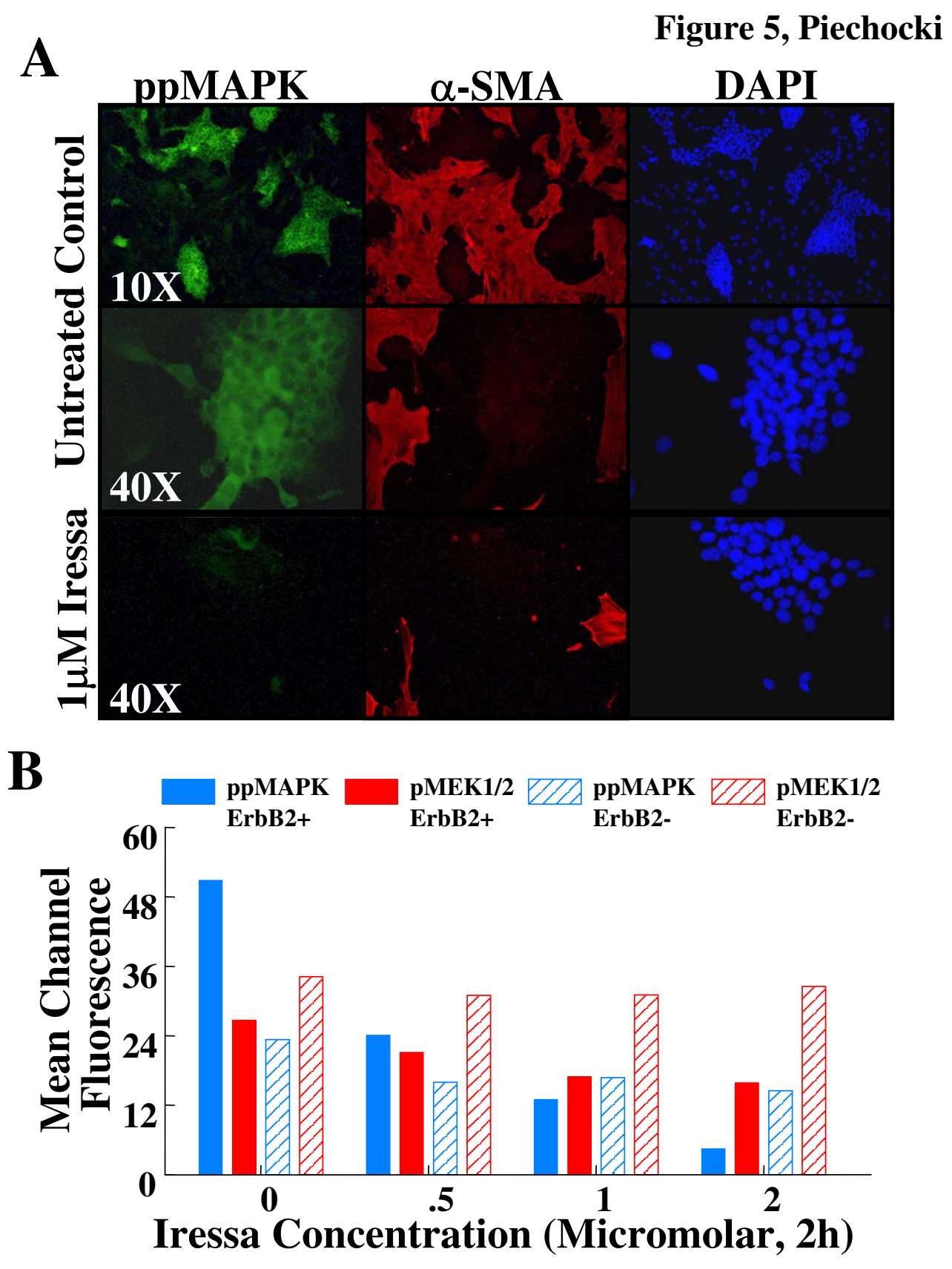

\section{Figure 5}

Effect of Iressa on phosphorylation of p44/42 MAPK by (A) Immunofluorescence and phosphorylation of p44/ 42 MAPK and MEKI/2 by (B) flow cytometry in MAM-I co-cultures. MAM-I were subcultured on coverslips or in 6well plates and grown to $\sim 95 \%$ confluence and then treated by replacing the conditioned media with fresh media that contained diluent (.001\% DMSO, Control) or Iressa for 2 hours prior to fixing and evaluation as described in the methods. A. Immunofluorescent photomicrographs were taken with the indicated objectives of cells that were double labeled for phosphop44/42 MAPK (Thr202/Tyr204) in green (FITC) and $\alpha$-SMA in red (TRITC) and counterstained with DAPI (blue) to define the nuclei. B. Dose-response for phosphorylation of P44/42 MAPK and MEKI/2 in MAM-I co-cultures by flow cytometry. MAM-I were treated as described above and dual-labeled for ErbB-2 and the indicated phospho-specific antigen. Bars represent Mean channel fluorescent values for Pp44/42 MAPK (Thr202/Tyr204) (Blue Bars) or PMEKI/2 (Ser2I7/22I) (Red Bars) in ErbB2+ (Solid Bars) and ErbB2-(Shaded Bars) subpopulations. 

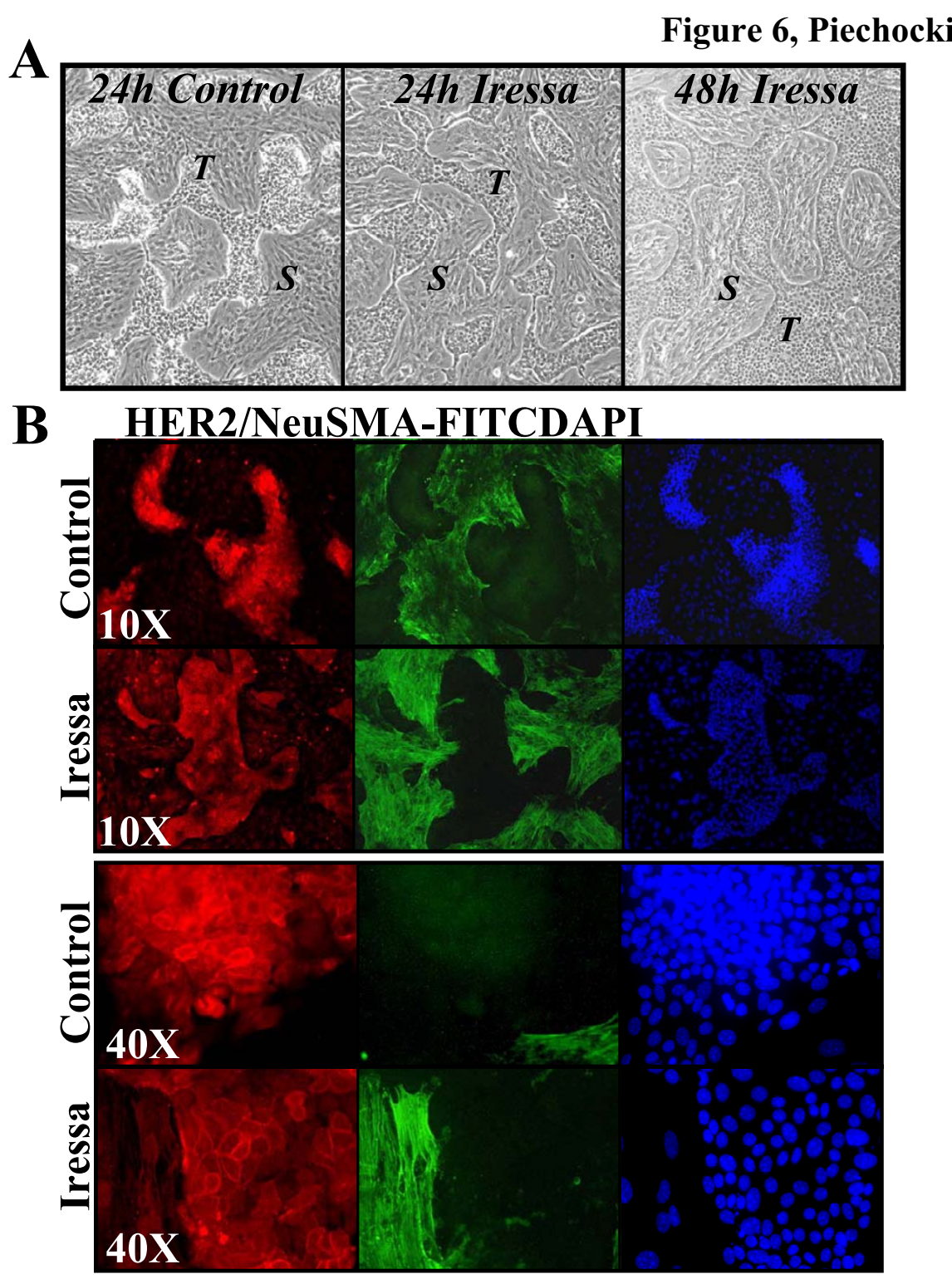

\section{Figure 6}

Differential Effects of Iressa on growth and morphology. MAM-I co-cultures were treated for $24-48 \mathrm{~h}$ by replacing conditioned media with fresh media in the absence (Control) or presence of I $\mu \mathrm{M}$ Iressa. A. Phase contrast photomicrographs of MAM-I co-cultures following treatment with I $\mu$ M Iressa were taken using a I0x objective. Tumor cell nests $(T)$ decrease in cellularity over time and stromal cells $(S)$ thicken and increase in cellularity. By $48 \mathrm{~h}$ tumor cell nests erode, cells flatten, and show evidence of apoptosis while stromal cells develop into multi-cell layer nests recapitulating the morphology of a fibrotic response in vitro. B. Immunofluorescence of MAM-I that were dual-labeled with HER2/neu-TRITC and $\alpha$-SMA-FITC to identify the tumor (red) and stromal (green) subpopulations, respectively. Photographs taken under low power (I0x) show decreased cellularity of HER2 ${ }^{+}$nests (red) and increased cellularity and density in the $\alpha-S M A^{+}$stroma (green). These shifts in the cellularity of the separate subpopulations are emphasized by the nuclear counterstain with DAPI (blue). Under higher magnification (40x) HER2 ${ }^{+}$nests of tumor cells (red) have decreased in cellularity and flattened into a monolayer while the cellularity and $\alpha$-SMA reactivity has increased in the stromal elements surrounding the tumor cells generating the thickened appearance that is associated with fibrosis. Note in particular the membrane accentuation of HER2/neu in the tumor cells treated with Iressa and the dense bundles of a-SMA reactive fibers in Iressa treated stroma. 


\section{Figure 7, Piechocki}
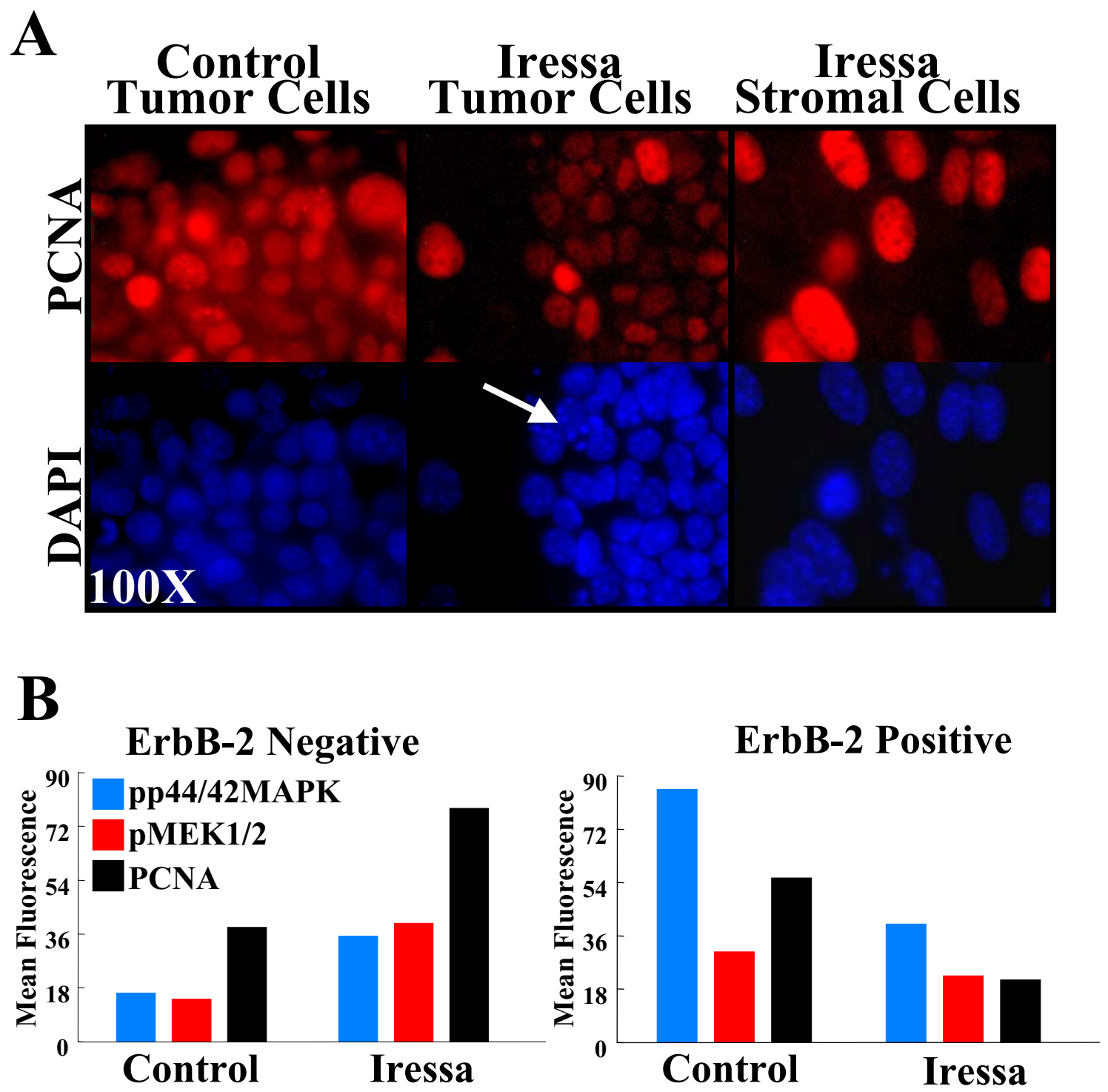

\section{Figure 7}

Effect of Iressa on (A) PCNA activity and (B) Signal transduction in the tumor and stromal cell populations of MAM-I co-cultures. A. MAM-I co-cultures were treated for $24 \mathrm{~h}$ with fresh media in the absence (Control) or presence of I $\mu$ M Iressa then fixed and stained with PCI0-TRITC to detect PCNA reactivity (red) and counterstained with DAPI to identify the nuclei (blue) Photomicrographs were taken with the 100x objective under oil immersion. The PCNA index of control tumor cells is $>95 \%$ and $<12 \%$ in the Iressa treated tumor cells. In the stroma adjacent to the Iressa treated tumor nest, PCNA index is $>95 \%$. Note the presence of apoptotic cells in DAPI stained tumor cells treated with Iressa (arrow). B. Differential effect of Iressa on PCNA, phospho-p44/42 MAPK (Thr202/Tyr204) and phospho-MEK I/2 (Ser2I7/22I) in the ErbB-2 Negative (Stromal) and ErbB-2 Positive (Tumor) populations in MAM-I treated for $24 \mathrm{~h}$ with I $\mu$ M Iressa. Samples were dual-labeled for ErbB-2 and the indicated antigen and evaluated by dual-color flow cytometry. Bars represent the Mean Channel Fluorescent Values for phospho-p44/42 MAPK (Blue Bars), phospho-MEKI/2 (Red Bars) or PCNA (Black Bars). Following Iressa treatment, the ErbB-2 positive population decreased by $44 \%$ and the $\alpha$-SMA positive population increased 3 -fold in these MAM-I co-cultures. 
suggest that Iressa preferentially targets signal transduction from the tumor cell HER2/neu leading to tumor cell death and a fibro-proliferative response in the stroma. In this co-culture model tumor cells retain their intrinsic sensitivity to Iressa and the tumor associated myofibroblasts of the stroma demonstrate intrinsic resistance to Iressa. Understanding the tumor regulatory properties of this microenvironment before, during and after treatment will be critical in determining the most appropriate treatment modality to prevent progression and recurrence.

\section{Competing interests}

The author declares that they have no competing interests.

\section{Additional material}

\section{Additional file 1}

MAM-1 Transcriptome. Data provides an annotated table listing $>2000$ genes elucidated by microarray analysis that are highly expressed ( $>2$-fold relative to universal mouse RNA) in the MAM-1 model.

Click here for file

[http://www.biomedcentral.com/content/supplementary/14712407-8-119-S1.xls]

\section{Additional file 2}

Differentially expressed genes between MAM-1 and Bam1a. Data provides an annotated table listing $>560$ genes elucidated by microarray analysis that are differentially expressed ( $>3$-fold) between the cloned breast cancer cell line, Bam1a, and MAM-1

Click here for file

[http://www.biomedcentral.com/content/supplementary/14712407-8-119-S2.xls]

\section{Acknowledgements}

Dr. Marie P. Piechocki is a Research Scholar of the American Cancer Society. This work was generously supported by a grant from the American Cancer Society (RSG-03-086-0 ITBE). Special thanks to Dr. Guido Forni, (Department of Clinical and Biological Sciences, University of Turin, Orbassano, Italy and Center for Experimental Research and Medical Studies, Ospedale San Giovanni Battista, Turin, Italy) for generously providing the Balb-NeuT transgenic mice and Dr. Fulvio Lonardo of the Department of Pathology at Wayne State University and the Pathology Core for assistance in evaluating the tissue biopsies.

\section{References}

I. Woodburn JR: The epidermal growth factor receptor and its inhibition in cancer therapy. Pharmacol Ther 1999, 8:24I-50.

2. Ullrich A, Schlessinger J: Signal transduction by receptors with tyrosine kinase activity. Cell 1990, 61:203-12.

3. Hynes NE, Lane HA: ERBB receptors and cancer: the complexity of targeted inhibitors. Nat Rev Cancer 2005, 5(5):341-54. Review. Erratum in: Nat Rev Cancer 2005;5(7):580

4. Herbst RS, Fukuoka M, Baselga J: Gefitinib - a novel targeted approach to treating cancer. Nat Rev Cancer 2004, 4( I 2):956-65. Review

5. Piechocki MP, Yoo GH, Dibbley SK, Amjad EH, Lonardo F: Iressa induces cytostasis and augments Fas-mediated apoptosis in acinic cell adenocarcinoma overexpressing HER2/neu. Int J Cancer 2006, I I 9(2):44I-54.
6. Piechocki MP, Yoo GH, Dibbley SK, Lonardo F: Breast Cancer expressing the activated HER2/neu is sensitive to Gefitinib in vitro and in vivo and acquires resistance through a novel point mutation in the HER2/neu. Cancer Res 2007, 67(14):6825-43.

7. Piechocki MP, Dibbley SK, Lonardo F, Yoo GH: Gefitinib prevents cancer progression in mice expressing the activated rat HER2/neu. Int J Cancer 2008, 122(8): 1722-9.

8. Dong-Le Bourhis X, Berthois Y, Millot G, Degeorges A, Sylvi M, Martin PM, Calvo F: Effect of stromal and epithelial cells derived from normal and tumorous breast tissue on the proliferation of human breast cancer cell lines in co-culture. Int J Cancer 1997, 7 I (I):42-8.

9. Saad S, Bendall LJ, James A, Gottlieb DJ, Bradstock KF: Induction of matrix metalloproteinases MMP-I and MMP-2 by co-culture of breast cancer cells and bone marrow fibroblasts. Breast Cancer Res Treat 2000, 63(2): 105-15.

10. Wang CS, Goulet F, Auger F, Tremblay N, Germain L, Tetu B: Production of bioengineered cancer tissue constructs in vitro: epithelium-mesenchyme heterotypic interactions. In Vitro Cell Dev Biol Anim 200I, 37(7):434-9.

II. Kunz-Schughart LA, Heyder P, Schroeder J, Knuechel R: A heterologous 3-D coculture model of breast tumor cells and fibroblasts to study tumor-associated fibroblast differentiation. Exp Cell Res 200I, 266(1):74-86.

12. Gudjonsson T, Ronnov-Jessen L, Villadsen R, Bissell MJ, Petersen $O W$ : To create the correct microenvironment: three-dimensional heterotypic collagen assays for human breast epithelial morphogenesis and neoplasia. Methods 2003, 30(3):247-55.

13. Eigeliene N, Harkonen P, Erkkola R: Effects of estradiol and medroxyprogesterone acetate on morphology, proliferation and apoptosis of human breast tissue in organ cultures. $B M C$ Cancer 2006, 6:246.

14. Gudjonsson T, Ronnov-Jessen L, Villadsen R, Rank F, Bissell MJ, Petersen OW: Normal and tumor-derived myoepithelial cells differ in their ability to interact with luminal breast epithelial cells for polarity and basement membrane deposition. J Cell Sci 2002, II 5(Pt I):39-50.

15. Muthuswamy SK, Li D, Lelievre S, Bissell MJ, Brugge JS: ErbB2, but not ErbBI, reinitiates proliferation and induces luminal repopulation in epithelial acini. Nat Cell Biol 200I, 3(9):785-92.

16. Di Carlo E, Diodoro MG, Boggio K, Modesti A, Modesti M, Nanni P, Forni G, Musiani P: Analysis of mammary carcinoma onset and progression in HER-2/neu oncogene transgenic mice reveals a lobular origin. Lab Invest 1999, 79:126I-69.

17. Werb Z, Ashkenas J, MacAuley A, Wiesen JF: Extracellular matrix remodeling as a regulator of stromal-epithelial interactions during mammary gland development, involution and carcinogenesis. Braz J Med Biol Res 1996, 29(9): 1087-97.

18. Singer CF, Kronsteiner N, Marton E, Kubista M, Cullen KJ, Hirtenlehner K, Seifert M, Kubista E: MMP-2 and MMP-9 expression in breast cancer-derived human fibroblasts is differentially regulated by stromal-epithelial interactions. Breast Cancer Res Treat 2002, 72(I):69-77.

19. Lynch MD, Cariati M, Purushotham AD: Breast cancer, stem cells and prospects for therapy. Breast Cancer Res 2006, 8(3):2II. Review

20. Astolfi A, Landuzzi L, Nicoletti G, De Giovanni C, Croci S, Palladini A, Ferrini S, lezzi M, Musiani P, Cavallo F, Forni G, Nanni P, Lollini PL: Gene expression analysis of immune-mediated arrest of tumorigenesis in a transgenic mouse model of HER-2/neupositive basal-like mammary carcinoma. Am J Pathol 2005, 166(4): $1205-16$.

21. Sørlie T, Perou CM, Tibshirani R, Aas T, Geisler S, Johnsen H, Hastie T, Eisen MB, van de Rijn M, Jeffrey SS, Thorsen T, Quist H, Matese JC, Brown PO, Botstein D, Eystein Lønning P, Børresen-Dale AL: Gene expression patterns of breast carcinomas distinguish tumor subclasses with clinical implications. Proc Natl Acad Sci USA 200I, 98(19): 10869-74.

22. Landis MD, Seachrist DD, Montanez-Wiscovich ME, Danielpour D, Keri RA: Gene expression profiling of cancer progression reveals intrinsic regulation of transforming growth factorbeta signaling in ErbB2/Neu-induced tumors from transgenic mice. Oncogene 2005, 24(33):5173-90.

23. Bertucci F, Borie N, Ginestier C, Groulet A, Charafe-jauffret E, Adélaïde J, Geneix J, Bachelart L, Finetti P, Koki A, Hermitte F, Has- 
soun J, Debono S, Viens P, Fert V, Jacquemier J, Birnbaum D: Identification and validation of an ERBB2 gene expression signature in breast cancers. Oncogene 2004, 23(14):2564-75.

24. West RB, Nuyten DS, Subramanian S, Nielsen TO, Corless CL, Rubin BP, Montgomery K, Zhu S, Patel R, Hernandez-Boussard T, Goldblum JR, Brown PO, van de Vijver M, van de Rijn M: Determination of stromal signatures in breast carcinoma. PLoS Biol 2005, 3(6): el 87.

25. lacobuzio-Donahue CA, Argani P, Hempen PM, Jones J, Kern SE: The desmoplastic response to infiltrating breast carcinoma: gene expression at the site of primary invasion and implications for comparisons between tumor types. Cancer Res 2002, 62(18):535I-7.

26. Peduto L, Reuter VE, Sehara-Fujisawa A, Shaffer DR, Scher HI, Blobel CP: ADAMI 2 is highly expressed in carcinoma-associated stroma and is required for mouse prostate tumor progression. Oncogene 2006, 25(39):5462-6.

27. $\mathrm{Li} Y, \mathrm{Li} L$, Brown TJ, Heldin P: Silencing of hyaluronan synthase 2 suppresses the malignant phenotype of invasive breast cancer cells. Int I Cancer 2007, I 20( I 2):2557-67.

28. Suh KS, Crutchley JM, Koochek A, Ryscavage A, Bhat K, Tanaka T, Oshima A, Fitzgerald P, Yuspa SH: Reciprocal modifications of CLIC4 in tumor epithelium and stroma mark malignant progression of multiple human cancers. Clin Cancer Res 2007, I3(I):|2|-3|.

29. Ronnov-Jessen L, Villadsen R, Edwards JC, Petersen OW: Differential expression of a chloride intracellular channel gene, CLIC4, in transforming growth factor-betal-mediated conversion of fibroblasts to myofibroblasts. Am J Pathol 2002, I6I(2):47I-80.

30. Micke $P$, Ostman A: Exploring the tumour environment: cancer-associated fibroblasts as targets in cancer therapy. Expert Opin Ther Targets 2005, 9(6): 1217-33. Review

31. Suzuki H, Aoshiba K, Yokohori N, Nagai A: Epidermal growth factor receptor tyrosine kinase inhibition augments a murine model of pulmonary fibrosis. Cancer Res 2003, 63(16):5054-9.

32. François H, Placier S, Flamant M, Tharaux PL, Chansel D, Dussaule JC, Chatziantoniou C: Prevention of renal vascular and glomerular fibrosis by epidermal growth factor receptor inhibition. FASEB / 2004, I 8(7):926-8.

33. Ishii Y, Fujimoto S, Fukuda T: Gefitinib prevents bleomycininduced lung fibrosis in mice. Am J Respir Crit Care Med 2006, I 74(5):550-6.

34. Sakai N, Wada T, Yokoyama H, Lipp M, Ueha S, Matsushima K, Kaneko S: Secondary lymphoid tissue chemokine (SLCl CCL2 I)/CCR7 signaling regulates fibrocytes in renal fibrosis. Proc Natl Acad Sci USA 2006, I03(38): 14098-103.

35. Inoue T, Fujishima S, Ikeda E, Yoshie O, Tsukamoto N, Aiso S, Aikawa $\mathrm{N}$, Kubo A, Matsushima K, Yamaguchi K: CCL22 and CCLI 7 in rat radiation pneumonitis and in human idiopathic pulmonary fibrosis. Eur Respir J 2004, 24(I):49-56.

36. Zhang C, Zhu Z, Liu J, Yang X, Fu L, Deng A: Role of connective tissue growth factor in extracellular matrix degradation in renal tubular epithelial cells. J Huazhong Univ Sci Technolog Med Sci 2007, 27(I):44-7.

37. Beirowski B, Weber M, Gross O: Chronic renal failure and shortened lifespan in COL4A3+/-mice: an animal model for thin basement membrane nephropathy. J Am Soc Nephrol 2006, I7(7): 1986-94.

\section{Pre-publication history}

The pre-publication history for this paper can be accessed here:

http://www.biomedcentral.com/1471-2407/8/119/pre pub
Publish with Biomed Central and every scientist can read your work free of charge

"BioMed Central will be the most significant development for disseminating the results of biomedical research in our lifetime. "

Sir Paul Nurse, Cancer Research UK

Your research papers will be:

- available free of charge to the entire biomedical community

- peer reviewed and published immediately upon acceptance

- cited in PubMed and archived on PubMed Central

- yours - you keep the copyright
Biomedcentral 